\title{
Koppelingen van classificaties voor het gebruik van arbeidsmarktinformatie over het middelbaar beroepsonderwijs
}

Citation for published version (APA):

Cörvers, F., \& Dijksman, S. (2002). Koppelingen van classificaties voor het gebruik van arbeidsmarktinformatie over het middelbaar beroepsonderwijs. Researchcentrum voor Onderwijs en Arbeidsmarkt, Faculteit der Economische Wetenschappen. ROA Reports No. 16 https://doi.org/10.26481/umarep.2002016

Document status and date:

Published: 01/01/2002

DOI:

10.26481/umarep.2002016

Document Version:

Publisher's PDF, also known as Version of record

\section{Please check the document version of this publication:}

- A submitted manuscript is the version of the article upon submission and before peer-review. There can be important differences between the submitted version and the official published version of record. People interested in the research are advised to contact the author for the final version of the publication, or visit the DOI to the publisher's website.

- The final author version and the galley proof are versions of the publication after peer review.

- The final published version features the final layout of the paper including the volume, issue and page numbers.

Link to publication

\footnotetext{
General rights rights.

- You may freely distribute the URL identifying the publication in the public portal. please follow below link for the End User Agreement:

www.umlib.nl/taverne-license

Take down policy

If you believe that this document breaches copyright please contact us at:

repository@maastrichtuniversity.nl

providing details and we will investigate your claim.
}

Copyright and moral rights for the publications made accessible in the public portal are retained by the authors and/or other copyright owners and it is a condition of accessing publications that users recognise and abide by the legal requirements associated with these

- Users may download and print one copy of any publication from the public portal for the purpose of private study or research.

- You may not further distribute the material or use it for any profit-making activity or commercial gain

If the publication is distributed under the terms of Article $25 \mathrm{fa}$ of the Dutch Copyright Act, indicated by the "Taverne" license above, 


\section{Koppelingen van classificaties voor het gebruik van arbeidsmarktinformatie over het middelbaar beroepsonderwijs}

ROA-R-2002/16

Frank Cörvers

Sander Dijksman

Researchcentrum voor Onderwijs en Arbeidsmarkt

Faculteit der Economische Wetenschappen en Bedrijfskunde Universiteit Maastricht

Maastricht, november 2002 
ISBN 90-5321-348-1

Sec02.190.doc 


\section{Inhoud}

Bladzijde

Voorwoord

1 Kenniscentra en bijbehorende opleidingstypen 1

1.1 Kenniscentra per opleidingstype 1

1.2 Opleidingstypen per kenniscentrum 4

2 Informatie per kenniscentrum $\quad 7$

2.1 AEQUOR (Kennis- en communicatiecentrum voor het groene beroepsonderwijs en bedrijfsleven)

2.2 BOUWRADIUS (Kenniscentrum beroepsonderwijs bedrijfsleven voor de burgerlijke en utiliteitsbouw)

2.3 ECABO (Kenniscentrum beroepsonderwijs bedrijfsleven voor de economisch-administratieve, ICT- en veiligheidsberoepen)

2.4 GOC (Kenniscentrum voor onderwijs, arbeidsmarkt en training \& advies in de grafimediabranche)

2.5 INNOVAM (Het opleidings- en examencentrum van de mobiliteitsbranche)

2.6 INTECHNIUM (Het kennis- en technologiecentrum voor de installatietechniek)

2.7 KC HANDEL (Kenniscentrum Handel)

2.8 KOC Nederland (Kenniscentrum voor uiterlijke verzorging) 22

2.9 Lift Groep (Het onderwijscentrum textiel en conferentie) 23

2.10 LOB HTV (Landelijk orgaan beroepsonderwijs horeca, toerisme en voeding)

2.11 Opleidingscentrum SVS (Opleidingscentrum voor het schilders- en stukadoorsbedrijf \& reclame- en presentatietechnieken)

2.12 OVDB (Landelijk orgaan van het beroepsonderwijs gezondheidszorg, dienstverlening, welzijn en sport)

2.13 SBW (Opleider voor de infrastructuur)

2.15 SOM opleidingen metaal (Kenniscentrum beroepsonderwijs bedrijfsleven voor metaal en werktuigbouwkunde)

2.16 SVGB Onderwijscentrum (Stichting vakopleiding voor gezondheidstechnische en ambachtelijke beroepen)

2.17 SVO (Kennis- en opleidingscentrum voor de foodsector) 40

2.18 VT en L (Vakopleiding transport en logistiek) 42

2.19 VaPro-OVP (Stichting vakopleiding procesindustrie) 44

2.20 VEV (Vereniging elektronisch vakonderwijs) 46

2.21 VOC (Stichting vakopleiding carosseriebedrijf) 48 
3.1 Belangrijkste beroepsgroepen per opleidingstype, gemiddelde 20002001

3.2 Uitwijkmogelijkheden naar verschillende beroepsgroepen per opleidingstype, gemiddelde 2000-2001

4 Belangrijkste bedrijfssectoren

4.1 Belangrijkste bedrijfssectoren per opleidingstype, gemiddelde 2000-2001

4.2 Uitwijkmogelijkheden naar verschillende bedrijfssectoren per opleidingstype, gemiddelde $2000-2001$ 


\section{Voorwoord}

Het voorliggende rapport is tot stand gekomen in het kader van de deelname van COLO Vereniging Kenniscentra Beroepsonderwijs Bedrijfsleven aan het Project Onderwijs-Arbeidsmarkt van het ROA. Daarbij is het de bedoeling om de Kenniscentra de mogelijkheid te geven om het informatiesysteem van het Project Onderwijs-Arbeidsmarkt (POA) optimaal te gebruiken. Op deze wijze kunnen de Kenniscentra hun inzicht verbreden over de aansluiting tussen onderwijs en arbeidsmarkt, en kunnen zij tevens feedback geven op het informatiegehalte en de gebruiksvriendelijkheid van het informatiesysteem. Voor een optimaal gebruik van het informatiesysteem is echter een koppeling noodzakelijk van de opleidingsindelingen zoals de Kenniscentra en het ROA die hanteren. In dit rapport wordt de koppeling tussen beide indelingen in diverse tabellen aangegeven.

De Kenniscentra Beroepsonderwijs Bedrijfsleven (KBB) van COLO zijn bedrijfstakgewijs georganiseerd. De taken die zij uitvoeren hebben een wettelijke basis en zijn vastgelegd in de Wet Educatie en Beroepsonderwijs (WEB). De Kenniscentra ontwikkelen kwalificaties voor het secundair beroepsonderwijs, controleren de examinering door onderwijsinstellingen, werven nieuwe leerbedrijven en bewaken ook de kwaliteit van de leerbedrijven. Op deze wijze zorgen Kenniscentra ervoor dat er voldoende nieuw en gekwalificeerd talent instroomt in hun bedrijfstak.

De beroepsopleidingen die horen bij een bepaald Kenniscentrum zijn geclassificeerd met een CREBO-code. Het CREBO (Centraal Register Beroepsopleidingen) is een systematisch geordende verzameling gegevens met betrekking tot de beroepsopleidingen die door zowel bekostigde als niet-bekostigde instellingen worden aangeboden. De minister van Onderwijs, Cultuur en Wetenschappen is belast met de aanleg, het beheer en de bekendmaking van het register en het verstrekken van informatie uit het register.

Bij de opleidingsclassificatie van het ROA is ernaar gestreefd om clusters van opleidingen te vormen die vanuit het oogpunt van de arbeidsmarkt een duidelijk verwantschap tonen. Daartoe heeft het ROA een clustering van opleidingen vastgesteld die in een hoge mate hetzelfde beroependomein kennen. ${ }^{1}$ Met betrekking tot de opleidingen hanteert het ROA een indeling in 113 opleidingstypen. Deze zijn gekoppeld aan de Standaard Onderwijsindeling 1978 (SOI '78). ${ }^{2}$ De Standaard Onderwijsindeling (SOI) is een classificatie van opleidingen naar niveau en richting, samengesteld door het Centraal Bureau voor de Statistiek (CBS). Bij het samenstellen van de SOI maakt het CBS gebruik van recente bronnen voor nieuwe opleidingen, welke jaarlijks beschikbaar komen voor de updates van de SOI. Dit zijn het Centraal

1. Zie H. Heijke, A. Matheeuwsen, E. Willems (2002), Clustering educational categories in a heterogeneous labour market, Education Economics, forthcoming.

2. Het CBS heeft inmiddels een vernieuwde Standaard Onderwijsindeling, de SOI '98, met zes in plaats van vijf digits. Met de extra digit is het mogelijk de WEB-niveaus in het middelbaar beroepsonderwijs te onderscheiden. De extra digit is echter nog niet bruikbaar in combinatie met de Enquête Beroepsbevolking. 
Register beroepsopleidingen (CREBO), en het Centraal Register Opleidingen Hoger Onderwijs ( $\mathrm{CROHO}$ ) en het LDC Expertisecentrum voor Loopbaanvraagstukken, dat periodiek informatie over opleidingen in het particulier onderwijs beschikbaar stelt. Met behulp van de conversie van CREBO-codes naar SOI-codes kunnen we een koppeling maken van opleidingen behorende bij een KBB en een ROA-opleidingstype.

Het rapport is opgedeeld in vier hoofdstukken. In het eerste hoofdstuk wordt het resultaat van de koppeling gepresenteerd in twee tabellen. De Kenniscentra kunnen zien waar ze volgens de ROA-indeling van opleidingen geclassificeerd zijn en het wordt duidelijk welke andere KBB's opleidingen aanbieden die binnen hetzelfde ROA-opleidingsype vallen. Hoofdstuk 2 is erop gericht om voor iedere KBB afzonderlijk een overzicht te geven van de koppeling van classificaties. Aan alle Kenniscentra is gevraagd om aan te geven op welke beroepen en bedrijven zij zich richten. Deze informatie is vertaald naar de classificaties die door het ROA worden gebruikt. Van de meest voorkomende opleidingstypen per KBB wordt een praktische toepassing weergegeven, namelijk de belangrijkste beroepsgroepen en bedrijfssectoren per opleidingstype. In hoofdstuk drie en vier wordt de invalshoek vanuit de afzonderlijke Kenniscentra losgelaten. Hoofdstuk 3 richt zich op de informatie van het opleidingstype in combinatie met de beroepsgroepen. De tabel over de belangrijkste beroepsgroepen per opleidingstype geeft weer hoe de verdeling van werkenden met een bepaald opleidingtype is over de beroepen. De uitwijkmogelijkheden naar verschillende beroepsgroepen per opleidingstype geeft aan in welke mate arbeidskrachten met een bepaalde opleidingsachtergrond in verschillende beroepsgroepen werkzaam zijn. Deze maatstaf geeft daarmee aan in hoeverre arbeidskrachten afhankelijk zijn van de arbeidsmarktsituatie in een bepaalde beroepsgroep. De uitwijkmogelijkheden worden bepaald met behulp van de Gini-Hirschman-spreidingsindex. Deze indicator kan geïnterpreteerd worden als een genormeerd aantal beroepsgroepen waarin mensen met dit opleidingstype werkzaam zijn. Hoofdstuk 4 richt zich op de verdeling van werkenden met een bepaald opleidingstypen over de bedrijfssectoren. De tabel over de uitwijkmogelijkheden naar bedrijfssectoren per opleidingstype geeft aan in welke mate arbeidskrachten met een bepaalde opleiding werkzaam zijn in verschillende bedrijfssectoren. Deze maatstaf geeft daarmee aan in hoeverre arbeidskrachten afhankelijk zijn van de arbeidsmarktsituatie in een bepaalde bedrijfssector. De uitwijkmogelijkheden worden bepaald met behulp van de GiniHirschman-spreidingsindex. Deze indicator kan geïnterpreteerd worden als genormeerd aantal bedrijfssectoren waarin mensen met dit opleidingstype werkzaam zijn. ${ }^{3}$

Dit rapport is samengesteld door S. Dijksman, onder verantwoordelijkheid van dr. F. Cörvers. Voorts heeft prof. dr. H. Heijke enkele waardevolle suggesties gedaan gedurende het verloop van het onderzoek. We danken dhr. C. Wielemaker (COLO), dhr. K. Hagens (Rijnland Advies) en dhr. O. Hermkens (Rijnland Advies) voor de prettige samenwerking, en dhr. J. Oud (CBS) voor het ter beschikking stellen van het conversiebestand van CREBO naar SOI '78. Een speciaal woord van dank gaat uit

3. Zie hiervoor bijvoorbeeld Methodiek arbeidsmarktprognoses en -indicatoren 2001-2006, ROA-W-2002/4, Maastricht. 
naar de vertegenwoordigers van de Kenniscentra Beroepsonderwijs Bedrijfsleven voor het verstrekken van de noodzakelijke informatie over het arbeidsmarktsegment waarop hun Kenniscentrum zich richt, en voor hun deelname aan de workshop voorafgaande aan de publicatie van dit rapport: dhr J. van Amelsvoort (OVDB), dhr. S. van Baar (SVO), dhr. E. Bosch (KC Handel), dhr. R. Brans (SVS), dhr. R. Cloosterman (Lift Groep), dhr. L. van Dorst (KOC Nederland), mevr. A. van den Engel (VaPro), mevr. P. Heuts (OVDB), dhr. T. de Jong (SH \& M), mevr. T. Kerkhof (KOC Nederland), mevr. L. Kroon (SH \& M), dhr. M. van Mechelen (ECABO), dhr. J. Meinsma (VOC), mevr. G. Röling (OVDB), mevr. J. Tiegelaarvan 't Spijker (SVS), dhr. P. Tolsma (VOC), dhr. S. Wagenaar (SOM metaal), dhr. F. van Wersch (VT en L) en mevr. I. van Westrienen (Bouwradius). 



\section{Kenniscentra en bijbehorende opleidingstypen}

Tabel 1.1

Kenniscentra per opleidingstype

\begin{tabular}{|c|c|}
\hline Opleidingstype & KBB \\
\hline VMBO landbouw en natuurlijke omgeving & $\begin{array}{l}\text { VaPro } \\
\text { Aequor }\end{array}$ \\
\hline VMBO bouwtechniek & $\begin{array}{l}\text { Bouwradius } \\
\text { Opleidingscentrum SVS } \\
\text { SH\&M }\end{array}$ \\
\hline VMBO installatietechniek & Intechnium \\
\hline VMBO metaal: mechanische techniek & SOM (metaal) \\
\hline VMBO voertuigentechniek & $\begin{array}{l}\text { Innovam } \\
\text { Vocar }\end{array}$ \\
\hline VMBO elektrotechniek & VEV \\
\hline VMBO grafische techniek & GOC \\
\hline VMBO brood en banket & LOB HTV \\
\hline VMBO transport en logistiek & Vakopleiding T en L \\
\hline VMBO administratie, handel en mode & $\begin{array}{l}\text { KC Handel } \\
\text { ECABO } \\
\text { Innovam } \\
\text { SVGB } \\
\text { Lift Groep } \\
\text { SH\&M }\end{array}$ \\
\hline VMBO consumptief en levensmiddelentechniek & $\begin{array}{l}\text { LOB HTV } \\
\text { SVO } \\
\text { Aequor }\end{array}$ \\
\hline VMBO (uiterlijke) verzorging & $\begin{array}{l}\text { SVGB } \\
\text { OVDB }\end{array}$ \\
\hline VMBO beveiliging & ECABO \\
\hline MBO landbouw en veeteelt & Aequor \\
\hline MBO milieu en groene ruimte & $\begin{array}{l}\text { VaPro } \\
\text { Aequor }\end{array}$ \\
\hline MBO laboratorium & VaPro \\
\hline MBO bouw & $\begin{array}{l}\text { Bouwradius } \\
\text { Opleidingscentrum SVS } \\
\text { SH\&M } \\
\text { Intechnium }\end{array}$ \\
\hline
\end{tabular}


Tabel 1.1 (vervolg)

Kenniscentra per opleidingstype

Opleidingstype

KBB

MBO grond-, weg- en waterbouw

Bouwradius

SBW

Vakopleiding T en L

MBO installatietechniek

Bouwradius

Intechnium

$\mathrm{MBO}$ werktuigbouw en mechanische techniek

SOM (metaal)

$\mathrm{SH} \& \mathrm{M}$

Intechnium

Vakopleiding $\mathrm{T}$ en $\mathrm{L}$

MBO fijnmechanische techniek

SOM (metaal)

VaPro

SVGB

MBO motorvoertuigentechniek

SOM (metaal)

Innovam

Vocar

MBO vliegtuigtechniek

SOM (metaal)

VEV

MBO operationele techniek

SOM (metaal)

VaPro

SBW

MBO elektrotechniek

SOM (metaal)

VEV

MBO grafische techniek

VaPro

GOC

MBO procestechniek

VaPro

MBO brood en banket

VaPro

SVGB

LOB HTV

MBO levensmiddelentechniek/vleesverwerking

SVO

Aequor

MBO vervoer en logistiek

ECABO

Vakopleiding T en L

MBO dokters-, tandarts- en dierenartsassistent

OVDB

MBO apothekersassistent

OVDB

$\mathrm{MBO}$ verpleging

SVGB

OVDB

MBO gezondheidstechniek

SVGB 
Tabel 1.1 (vervolg)

Kenniscentra per opleidingstype

Opleidingstype

KBB

MBO sociaal-cultureel

ECABO

OVDB

$\mathrm{MBO}$ verzorging

OVDB

MBO uiterlijke verzorging

KOC

MBO horeca

LOB HTV

MBO beweging en therapie

OVDB

MBO administratie

KC Handel

ECABO

Vakopleiding T en L

MBO handel

KC Handel

ECABO

Bouwradius

Opleidingscentrum SVS

Innovam

SVGB

Lift Groep

SH\&M

Aequor

MBO secretariaat

ECABO

LOB HTV

MBO toerisme en recreatie

LOB HTV

Vakopleiding T en L

MBO bedrijfskunde

SOM (metaal)

Vakopleiding T en L

MBO automatisering

ECABO

VEV

MBO geld, bank en belastingen

ECABO

$\mathrm{MBO}$ verzekeringswezen

ECABO

MBO openbare orde en veiligheid

ECABO

VaPro 
Tabel 1.2

Opleidingstypen per kenniscentrum

KBB

Opleidingstype

KC Handel

ECABO

SOM (metaal)

VaPro

Bouwradius

Opleidingscentrum SVS

Innovam

Vocar
VMBO administratie, handel en mode

MBO administratie

MBO handel

VMBO administratie, handel en mode VMBO beveiliging

$M B O$ vervoer en logistiek

MBO sociaal-cultureel

MBO administratie

MBO handel

MBO secretariaat

MBO automatisering

MBO geld, bank en belastingen

$M B O$ verzekeringswezen

MBO openbare orde en veiligheid

VMBO metaal: mechanische techniek

MBO werktuigbouw en mechanische techniek

MBO fijnmechanische techniek

MBO motorvoertuigentechniek

MBO vliegtuigtechniek

MBO operationele techniek

MBO elektrotechniek

MBO techniek overig

MBO bedrijfskunde

VMBO landbouw en natuurlijke omgeving

MBO milieu en groene ruimte

MBO laboratorium

MBO fijnmechanische techniek

MBO operationele techniek

MBO grafische techniek

MBO procestechniek

MBO brood en banket

MBO openbare orde en veiligheid

VMBO bouwtechniek

MBO bouw

MBO grond-, weg- en waterbouw

MBO installatietechniek

MBO handel

VMBO bouwtechniek

MBO bouw

MBO handel

VMBO voertuigentechniek

VMBO administratie, handel en mode

MBO motorvoertuigentechniek

MBO handel

VMBO voertuigentechniek

MBO motorvoertuigentechniek 
Tabel 1.2 (vervolg)

Opleidingstypen per kenniscentrum

KBB

Opleidingstype

VEV

VMBO elektrotechniek

MBO vliegtuigtechniek

MBO elektrotechniek

MBO automatisering

SVGB

VMBO administratie, handel en mode

VMBO (uiterlijke) verzorging

MBO fijnmechanische techniek

MBO brood en banket

$\mathrm{MBO}$ verpleging

MBO gezondheidstechniek

MBO handel

GOC

VMBO grafische techniek

MBO grafische techniek

Lift Groep

VMBO administratie, handel en mode

MBO handel

LOB HTV

VMBO brood en banket

VMBO consumptief en levensmiddelentechniek

MBO brood en banket

MBO horeca

MBO secretariaat

$\mathrm{MBO}$ toerisme en recreatie

OVDB

VMBO (uiterlijke) verzorging

MBO dokters-, tandarts- en dierenartsassistent

$\mathrm{MBO}$ apothekersassistent

$\mathrm{MBO}$ verpleging

MBO sociaal-cultureel

$\mathrm{MBO}$ verzorging

MBO beweging en therapie

SBW

MBO grond-, weg- en waterbouw

MBO operationele techniek

SH\&M

VMBO bouwtechniek

VMBO administratie, handel en mode

MBO bouw

MBO werktuigbouw en mechanische techniek

MBO hande

$\mathrm{KOC}$

MBO uiterlijke verzorging

SVO

VMBO consumptief en levensmiddelentechniek MBO levensmiddelentechniek/vleesverwerking

Intechnium

VMBO installatietechniek

MBO bouw

MBO installatietechniek

MBO werktuigbouw en mechanische techniek 
Tabel 1.2 (vervolg)

Opleidingstypen per kenniscentrum

KBB

Opleidingstype

Aequor
VMBO landbouw en natuurlijke omgeving

VMBO consumptief en levensmiddelentechniek

$\mathrm{MBO}$ landbouw en veeteelt

MBO milieu en groene ruimte

MBO levensmiddelentechniek/vleesverwerking

MBO handel

VMBO transport en logistiek

MBO grond-, weg- en waterbouw

$\mathrm{MBO}$ werktuigbouw en mechanische techniek

$M B O$ vervoer en logistiek

$\mathrm{MBO}$ administratie

MBO toerisme en recreatie

MBO bedrijfskunde 


\section{Informatie per kenniscentrum}

Tabel 2.1

AEQUOR (Kennis- en communicatiecentrum voor het groene beroepsonderwijs en bedrijfsleven)

ROA opleidingstype

VMBO landbouw en natuurlijke omgeving

VMBO consumptief en levensmiddelentechniek

$M B O$ landbouw en veeteelt

MBO milieu en groene ruimte

MBO levensmiddelentechniek/vleesverwerking

MBO handel

ROA opleidingstype

assistent beroepsbeoefenaar groene ruimte as bbl

assistent beroepsbeoefenaar plantenteelt as bbl

assistent beroepsbeoefenaar plantenteelt as bbl

assistent beroepsbeoefenaar levensmiddelentechnologie bbl

assistent beroepsbeoefenaar levensmiddelentechnologie bol

beginnend beroepsbeoefenaar bd land- en tuinbouw bb bbl beginnend beroepsbeoefenaar bd land- en tuinbouw bb bol beginnend beroepsbeoefenaar bloemschikken bb bol

beginnend beroepsbeoefenaar bloemschikken bb bol beginnend beroepsbeoefenaar dierverzorging bb bbl beginnend beroepsbeoefenaar dierverzorging bb bbl beginnend beroepsbeoefenaar paardenhouderij en paardesport bb bbl

beginnend beroepsbeoefenaar paardenhouderij en paardesport bb bol

beginnend beroepsbeoefenaar plantenteelt bb bol beginnend beroepsbeoefenaar plantenteelt bb bol beginnend beroepsbeoefenaar veehouderij bb bbl beginnend beroepsbeoefenaar veehouderij bb bbl $\mathrm{gb}$ paardenhouderij en management $\mathrm{sp} \mathrm{bbl}$ gespecialiseerd beroepsbeoefenaar dierenonderneming $\mathrm{sp} \mathrm{bbl}$

gespecialiseerd beroepsbeoefenaar dierenzorg $\mathrm{sp} \mathrm{bbl}$ gespecialiseerd beroepsbeoefenaar loonwerk sp bbl gespecialiseerd beroepsbeoefenaar paardesport sp bbl gespecialiseerd beroepsbeoefenaar plantenteelt en handel $\mathrm{sp}$ bbl

gespecialiseerd beroepsbeoefenaar plantenteelt en management sp bbl

gespecialiseerd beroepsbeoefenaar veehouderij en management $\mathrm{sp}$ bol

kaderfunctionaris bd land- en tuinbouw mk bol kaderfunctionaris dierenonderneming $\mathrm{mk}$ bol kaderfunctionaris dierenzorg $\mathrm{mk}$ bol
VMBO landbouw en natuurlijke omgeving VMBO landbouw en natuurlijke omgeving VMBO landbouw en natuurlijke omgeving VMBO consumptief en levensmiddelentechniek VMBO consumptief en levensmiddelentechniek MBO landbouw en veeteelt MBO landbouw en veeteelt MBO landbouw en veeteelt MBO landbouw en veeteelt $\mathrm{MBO}$ landbouw en veeteelt MBO landbouw en veeteelt

MBO landbouw en veeteelt

MBO landbouw en veeteelt MBO landbouw en veeteelt MBO landbouw en veeteelt MBO landbouw en veeteelt $\mathrm{MBO}$ landbouw en veeteelt MBO landbouw en veeteelt

MBO landbouw en veeteelt MBO landbouw en veeteelt MBO landbouw en veeteelt MBO landbouw en veeteelt

MBO landbouw en veeteelt

MBO landbouw en veeteelt

MBO landbouw en veeteelt MBO landbouw en veeteelt MBO landbouw en veeteelt $\mathrm{MBO}$ landbouw en veeteelt 
Tabel 2.1 (vervolg)

AEQUOR (Kennis- en communicatiecentrum voor het groene beroepsonderwijs en bedrijfsleven)

kaderfunctionaris paardenhouderij en management $\mathrm{mk}$ bol kaderfunctionaris paardesport $\mathrm{mk}$ bol

kaderfunctionaris plantenteelt en handel $\mathrm{mk}$ bol kaderfunctionaris plantenteelt en management $\mathrm{mk}$ bol kaderfunctionaris plantenteelt en milieu $\mathrm{mk}$ bol kaderfunctionaris veehouderij en handel $\mathrm{mk}$ bol kaderfunctionaris veehouderij en management $\mathrm{mk}$ bol kaderfunctionaris veehouderij en milieu $\mathrm{mk}$ bol medewerker gemechaniseerd loonbedrijf bb bol medewerker gemechaniseerd loonbedrijf bb bol middenkaderfunctionaris bloemschikken $\mathrm{mk}$ bol specialist bloembinden $\mathrm{sp}$ bbl

technisch medewerker recreatiebedrijf $\mathrm{vk}$ bbl technisch medewerker recreatiebedrijf vk bbl $\mathrm{zb}$ tuincentrum $\mathrm{vk} \mathrm{bbl}$

$\mathrm{zb}$ tuincentrum $\mathrm{vk} \mathrm{bbl}$

zelfstandig beroepsbeoefenaar akkerbouw $\mathrm{vk}$ bol zelfstandig beroepsbeoefenaar akkerbouw $\mathrm{vk}$ bol zelfstandig beroepsbeoefenaar bd land- en tuinbouw vk bol zelfstandig beroepsbeoefenaar bloementeelt $\mathrm{vk} \mathrm{bbl}$ zelfstandig beroepsbeoefenaar bloementeelt $\mathrm{vk} \mathrm{bbl}$ zelfstandig beroepsbeoefenaar bollenteelt $\mathrm{vk}$ bol zelfstandig beroepsbeoefenaar bollenteelt $\mathrm{vk}$ bol zelfstandig beroepsbeoefenaar boomteelt $\mathrm{vk}$ bbl zelfstandig beroepsbeoefenaar boomteelt $\mathrm{vk}$ bbl zelfstandig beroepsbeoefenaar dierenonderneming $\mathrm{vk} \mathrm{bbl}$ zelfstandig beroepsbeoefenaar dierenonderneming $\mathrm{vk}$ bol zelfstandig beroepsbeoefenaar dierenzorg $\mathrm{vk}$ bol zelfstandig beroepsbeoefenaar dierenzorg $\mathrm{vk}$ bol zelfstandig beroepsbeoefenaar fruitteelt $\mathrm{vk} \mathrm{bbl}$ zelfstandig beroepsbeoefenaar fruitteelt $\mathrm{vk} \mathrm{bbl}$ zelfstandig beroepsbeoefenaar groenteteelt $\mathrm{vk} \mathrm{bbl}$ zelfstandig beroepsbeoefenaar groenteteelt $\mathrm{vk}$ bbl zelfstandig beroepsbeoefenaar hoefsmid $\mathrm{vk} \mathrm{bbl}$ zelfstandig beroepsbeoefenaar loonwerk $\mathrm{vk} \mathrm{bbl}$ zelfstandig beroepsbeoefenaar loonwerk $\mathrm{vk} \mathrm{bbl}$ zelfstandig beroepsbeoefenaar melkveehouderij vk bbl zelfstandig beroepsbeoefenaar melkveehouderij vk bol zelfstandig beroepsbeoefenaar paardenhouderij en paardesport vk bbl

zelfstandig beroepsbeoefenaar paardenhouderij en paardesport vk bol

zelfstandig beroepsbeoefenaar paardenhouderij vk bbl zelfstandig beroepsbeoefenaar paardenhouderij vk bol zelfstandig beroepsbeoefenaar paddestoelenteelt $\mathrm{vk} \mathrm{bbl}$ zelfstandig beroepsbeoefenaar paddestoelenteelt $\mathrm{vk}$ bol zelfstandig beroepsbeoefenaar pluimveehouderij vk bbl zelfstandig beroepsbeoefenaar pluimveehouderij vk bol zelfstandig beroepsbeoefenaar potplantenteelt $\mathrm{vk} b$ zelfstandig beroepsbeoefenaar potplantenteelt $v k b$ zelfstandig beroepsbeoefenaar tuincentrum $\mathrm{vk}$ bbl zelfstandig beroepsbeoefenaar tuincentrum $\mathrm{vk}$ bol zelfstandig beroepsbeoefenaar varkenshouderij vk bbl zelfstandig beroepsbeoefenaar varkenshouderij vk bol beginnend beroepsbeoefenaar groene ruimte bb bbl
MBO landbouw en veeteelt $\mathrm{MBO}$ landbouw en veeteelt MBO landbouw en veeteelt MBO landbouw en veeteelt $\mathrm{MBO}$ landbouw en veeteelt MBO landbouw en veeteelt MBO landbouw en veeteelt MBO landbouw en veeteelt MBO landbouw en veeteelt $\mathrm{MBO}$ landbouw en veeteelt MBO landbouw en veeteelt MBO landbouw en veeteelt MBO landbouw en veeteelt MBO landbouw en veeteelt $M B O$ landbouw en veeteelt MBO landbouw en veeteelt MBO landbouw en veeteelt MBO landbouw en veeteelt MBO landbouw en veeteelt $M B O$ landbouw en veeteelt MBO landbouw en veeteelt MBO landbouw en veeteelt MBO landbouw en veeteelt MBO landbouw en veeteelt $M B O$ landbouw en veeteelt MBO landbouw en veeteelt MBO landbouw en veeteelt MBO landbouw en veeteelt MBO landbouw en veeteelt $M B O$ landbouw en veeteelt MBO landbouw en veeteelt MBO landbouw en veeteelt MBO landbouw en veeteelt MBO landbouw en veeteelt MBO landbouw en veeteelt MBO landbouw en veeteelt MBO landbouw en veeteelt MBO landbouw en veeteelt

MBO landbouw en veeteelt

MBO landbouw en veeteelt MBO landbouw en veeteelt MBO landbouw en veeteelt MBO landbouw en veeteelt MBO landbouw en veeteelt MBO landbouw en veeteelt MBO landbouw en veeteelt MBO landbouw en veeteelt MBO landbouw en veeteelt MBO landbouw en veeteelt MBO landbouw en veeteelt MBO landbouw en veeteelt MBO landbouw en veeteelt MBO milieu en groene ruimte 
Tabel 2.1 (vervolg)

AEQUOR (Kennis- en communicatiecentrum voor het groene beroepsonderwijs en bedrijfsleven)

beginnend beroepsbeoefenaar groene ruimte bb $\mathrm{bbl}$ gb land-, water- en milieubeheer sp bbl gespecialiseerd beroepsbeoefenaar bos- en natuurbeheer sp bbl gespecialiseerd beroepsbeoefenaar groenbeheer $\mathrm{sp}$ bbl kaderfunctionaris bos- en natuurbeheer mk bol kaderfunctionaris groenbeheer $\mathrm{mk}$ bol

kaderfunctionaris land-, water- en milieubeheer mk kaderfunctionaris milieutoezicht $\mathrm{mk}$ bol zelfstandig beroepsbeoefenaar groot groen $\mathrm{vk}$ bol zelfstandig beroepsbeoefenaar groot groen $\mathrm{vk}$ bol zelfstandig beroepsbeoefenaar klein groen $\mathrm{vk}$ bol zelfstandig beroepsbeoefenaar klein groen $\mathrm{vk}$ bol zelfstandig beroepsbeoefenaar land, water en milieu $\mathrm{vk} \mathrm{bbl}$ zelfstandig beroepsbeoefenaar land, water en milieu vk bo beginnend beroepsbeoefenaar levensmiddelentechnologie bbl

beginnend beroepsbeoefenaar levensmiddelentechnologie bol gb levensmiddelentechnologie en kwaliteitszorg sp bbl

gb levensmiddelentechnologie en produkttechnologie sp bbl gespecialiseerd beroepsbeoefenaar mengvoederindustrie $\mathrm{sp} \mathrm{bbl}$ kaderfunctionaris kwaliteitszorg vleesketen $\mathrm{mk}$ bol kaderfunctionaris kwaliteitszorg vleesketen mk bol kaderfunctionaris mengvoederindustrie $\mathrm{mk}$ bol

kf levensmiddelentechnologie en kwaliteitszorg mk bol

$\mathrm{kf}$ levensmiddelentechnologie en milieutechnologie $\mathrm{mk}$ bol

kf levensmiddelentechnologie en produktcontrole $\mathrm{mk}$ bol

kf levensmiddelentechnologie en produkttechnologie mk bol

zb kwaliteitszorg vlees en vleesverwerking vk bol

zelfstandig beroepsbeoefenaar kwaliteitszorg vee en vlees vk bol

zelfstandig beroepsbeoefenaar levensmiddelentechnologie vk bbl

zelfstandig beroepsbeoefenaar levensmiddelentechnologie vk bol

beginnend beroepsbeoefenaar handel in plantenteeltprodukten bb bbl

beginnend beroepsbeoefenaar handel in plantenteeltprodukten bb bol
MBO milieu en groene ruimte MBO milieu en groene ruimte MBO milieu en groene ruimte MBO milieu en groene ruimte MBO milieu en groene ruimte MBO milieu en groene ruimte MBO milieu en groene ruimte MBO milieu en groene ruimte MBO milieu en groene ruimte MBO milieu en groene ruimte MBO milieu en groene ruimte MBO milieu en groene ruimte MBO milieu en groene ruimte MBO milieu en groene ruimte MBO levensmiddelentechniek /vleesverwerking

MBO levensmiddelentechniek /vleesverwerking

MBO levensmiddelentechniek /vleesverwerking

MBO levensmiddelentechniek vleesverwerking

MBO levensmiddelentechniek vleesverwerking

MBO levensmiddelentechniek /vleesverwerking

MBO levensmiddelentechniek /vleesverwerking

MBO levensmiddelentechniek /vleesverwerking

MBO levensmiddelentechniek vleesverwerking

MBO levensmiddelentechniek vleesverwerking

MBO levensmiddelentechniek /vleesverwerking

MBO levensmiddelentechniek /vleesverwerking

MBO levensmiddelentechniek /vleesverwerking

MBO levensmiddelentechniek /vleesverwerking

MBO levensmiddelentechniek /vleesverwerking

MBO levensmiddelentechniek /vleesverwerking

MBO handel

MBO handel 
Tabel 2.1 (vervolg)

AEQUOR (Kennis- en communicatiecentrum voor het groene beroepsonderwijs en bedrijfsleven)

$\mathrm{zb}$ handel in plantenteeltprodukten $\mathrm{vk}$ bbl

MBO handel

$\mathrm{zb}$ handel in plantenteeltprodukten $\mathrm{vk}$ bbl

MBO handel

$\mathrm{zb}$ handel in plantenteeltprodukten $\mathrm{vk}$ bol

MBO handel

$z b$ handel in plantenteeltprodukten $\mathrm{vk}$ bol

MBO handel

zelfstandig beroepsbeoefenaar bloemendetailhandel $\mathrm{vk} \mathrm{bbl}$

MBO handel

zelfstandig beroepsbeoefenaar bloemendetailhandel vk bol

MBO handel

ROA bedrijfssectoren van de belangrijkste ROA opleidingstypen, gemiddelde 2000-2001

$\begin{array}{ccl}\text { MBO landbouw en veeteelt } & \% & \text { trend 1997-2001 } \\ \text { Veehouderij } & 30 & \text { dalend } \\ \text { Handel en reparatie } & 18 & \text { sterk stijgend } \\ \text { Tuinbouw } & 14 & \text { stijgend } \\ \text { Akkerbouw, bosbouw en visserij } & 7 & \text { sterk dalend } \\ \text { Andere bedrijfssectoren } & 31 & \\ & & \\ \text { MBO milieu en groene ruimte } & \% & \text { trend 1997-2001 } \\ \text { Overheid } & 25 & \text { stijgend } \\ \text { Veehouderij } & 21 & \text { dalend } \\ \text { Handel en reparatie } & 9 & \text { dalend } \\ \text { Hout- en bouwmaterialen } & 9 & \text { sterk stijgend } \\ \text { Tuinbouw } & 7 & \text { sterk stijgend } \\ \text { Zakelijke dienstverlening } & 5 & \text { dalend } \\ \text { Andere bedrijfssectoren } & 22 & \end{array}$

ROA beroepsgroepen van de belangrijkste ROA opleidingstypen, gemiddelde 2000-2001

$\begin{array}{crl}\text { MBO landbouw en veeteelt } & \% & \text { trend 1997-2001 } \\ \text { Agrarische bedrijfshoofden } & 37 & \text { dalend } \\ \text { Agrarische arbeiders } & 15 & \text { constant } \\ \text { Verkopers } & 7 & \text { sterk stijgend } \\ \text { Andere beroepsgroepen } & 41 & \\ \text { MBO milieu en groene ruimte } & \% & \text { trend 1997-2001 } \\ \text { Agrarische arbeiders } & 46 & \text { constant } \\ \text { Agrarische bedrijfshoofden } & 11 & - \\ \text { Andere beroepsgroepen } & 43 & \\ & & \end{array}$


Tabel 2.2

BOUWRADIUS (Kenniscentrum beroepsonderwijs bedrijfsleven voor de burgerlijke en utiliteitsbouw)

ROA opleidingstype

VMBO bouwtechniek

MBO bouw

MBO grond-, weg- en waterbouw

MBO installatietechniek

MBO handel

ROA opleidingstype

bouwplaatsassistent

middenkaderopleiding afbouw

middenkaderopleiding bouwkunde

assistent uitvoerder burger en utiliteitsbouw

restauratiemedewerker

kaderfunctionaris betontimmerbedrijven

kaderfunctionaris tegelzetbedrijven

kaderfunctionaris betonstaalverwerkingsbedrijven

kaderfunctionaris natuursteenbedrijf

vakkracht bouwtechniek

restauratietimmerkracht

voortgezette metselaar

voortgezette timmerkracht

vakkracht houtskeletbouw

betonreparateur

natuursteenbewerker

betonmodelmaker

ovenbouwmetselaar

voeger

betontimmerkracht

betonstaalverwerker

tegelzetter

primaire metselaar

primaire timmerkracht

hulpvakkracht

steigerbouwer

voeger bb bbl

betontimmerkracht b\&u/civiel bb bbl

restauratiemedewerker bb bbl

metselaar bb bbl

middenkaderopleiding verkeer- en stedebouwkunde

voortgezette dakdekker

primaire dakdekker

medewerker tentoonstellingsbouw bb bbl
VMBO bouwtechniek

$\mathrm{MBO}$ bouw

MBO bouw

MBO bouw

MBO bouw

MBO bouw

MBO bouw

MBO bouw

MBO bouw

MBO bouw

MBO bouw

MBO bouw

MBO bouw

MBO bouw

MBO bouw

MBO bouw

MBO bouw

MBO bouw

$\mathrm{MBO}$ bouw

MBO bouw

MBO bouw

MBO bouw

MBO bouw

$\mathrm{MBO}$ bouw

MBO bouw

MBO bouw

MBO bouw

MBO bouw

MBO bouw

MBO bouw

MBO grond-, weg- en water-

bouw

MBO installatietechniek

MBO installatietechniek

MBO handel 
Tabel 2.2 (vervolg)

BOUWRADIUS (Kenniscentrum beroepsonderwijs bedrijfsleven voor de burgerlijke en utiliteitsbouw)

Bedrijfssector (SBI) volgens KBB

ROA Bedrijfssector

Aannemers

Bouw

Woningcorporaties

Bouw

Architecten, bouwadviesbureaus en bouwtechnische tekenbureaus

Zakelijke

dienstverlening

ROA bedrijfssectoren van het belangrijkste ROA opleidingstype, gemiddelde 2000-2001

MBO Bouw

Bouw

Hout- en bouwmaterialen

Zakelijke dienstverlening

Handel en reparatie

Andere bedrijfssectoren

8

6

trend 1997-2001

constant

dalend

stijgend

stijgend

ROA beroepsgroepen van het belangrijkste ROA opleidingstype, gemiddelde 2000-2001

MBO bouw

Aannemers en installateurs

Bouwvakkers

Architecten en bouwkundig projectleiders

trend 1997-2001

Andere beroepsgroepen

42 constant

23 constant

6 sterk stijgend 
Tabel 2.3

ECABO (Kenniscentrum beroepsonderwijs bedrijfsleven voor de economisch-administratieve, ICT- en veiligheidsberoepen)

ROA opleidingstype

VMBO administratie, handel en mode

VMBO beveiliging

MBO vervoer en logistiek

MBO sociaal-cultureel

MBO administratie

MBO handel

MBO secretariaat

MBO automatisering

MBO geld, bank en belastingen

$M B O$ verzekeringswezen

MBO openbare orde en veiligheidVMBO bouwtechniek

administratief medewerker

algemeen beveiligingsmedewerker

toezichthouder

particulier onderzoeker

assistent vrede en veiligheid as bo

toezichthouder beveiliging as bbl

medewerker logistiek management - material management

medewerker logistiek management - fysieke distibutie

logistiek medewerker material management

logistiek medewerker fysieke distributie

sociaal juridisch medewerker-arbeidsvoorz. en pers.werk

assistent bibliothecaris openbare bibliotheken

sociaal juridisch medewerker - sociale zekerheid

administratief juridisch medewerker-openbaar bestuur

administrateur

commercieel medewerker binnendienst

bedrijfsadministratief medewerker

commercieel administratief medewerker

boekhoudkundig medewerker

commercieel medewerker bank- en verzekeringswezen

commercieel medewerker marketing en communicatie

directiesecretaresse / management assistent

secretaresse

secretarieel medewerker

beheerder technische infrastructuur

applicatie ontwikkelaar

applicatiebeheerder

systeembeheerder mkb

netwerkbeheerder

ict - beheerder

medewerker beheer informatiesystemen

ict-medewerker

service medewerker-ict bb bbl

applicatiebeheerder sp bbl

applicatieontwikkelaar sp bbl

ict-beheerder $\mathrm{mk}$ bbl

medewerker beheer ict vk bbl
VMBO administratie, handel

en mode

VMBO beveiliging

VMBO beveiliging

VMBO beveiliging

VMBO beveiliging

VMBO beveiliging

$M B O$ vervoer en logistiek

$\mathrm{MBO}$ vervoer en logistiek

$\mathrm{MBO}$ vervoer en logistiek

MBO vervoer en logistiek

MBO sociaal-cultureel

MBO sociaal-cultureel

MBO administratie

MBO administratie

MBO administratie

MBO administratie

MBO administratie

MBO administratie

$\mathrm{MBO}$ administratie

MBO administratie

MBO handel

MBO secretariaat

MBO secretariaat

MBO secretariaat

MBO automatisering

$\mathrm{MBO}$ automatisering

MBO automatisering

MBO automatisering

MBO automatisering

MBO automatisering

MBO automatisering

MBO automatisering

MBO automatisering

MBO automatisering

MBO automatisering

MBO automatisering

MBO automatisering 
Tabel 2.3 (vervolg)

ECABO (Kenniscentrum beroepsonderwijs bedrijfsleven voor de economisch-administratieve, ICT- en veiligheidsberoepen)

Crebo opleiding ROA opleidingstype

netwerkbeheerder sp bbl

commercieel medewerker banken

commercieel medewerker verzekeringen

beveiligingsmedewerker

beveiligingsmedewerker bb bbl ECABO

beveiligingsmedewerker $\mathrm{bb} \mathrm{bbl}$

MBO automatisering

MBO geld, bank en

belastingen

MBO verzekeringswezen

MBO openbare orde en

veiligheid

MBO openbare orde en

veiligheid

MBO openbare orde en

veiligheid

ROA bedrijfssectoren van de belangrijkste ROA opleidingstypen, gemiddelde 2000-2001

\begin{tabular}{ccc} 
MBO administratie & $\%$ & trend 1997-2001 \\
Handel en reparatie & 18 & dalend \\
Zakelijke dienstverlening & 15 & constant \\
Overheid & 14 & constant \\
Bankwezen & 7 & stijgend \\
Gezondheidszorg & 6 & sterk stijgend \\
Andere bedrijfssectoren & 40 & \\
MBO automatisering & $\%$ & trend 1997-2001 \\
Zakelijke dienstverlening & 26 & constant \\
Handel en reparatie & 16 & sterk stijgend \\
Overheid & 11 & constant \\
Andere bedrijfssectoren & 46 & \\
& & \\
\hline
\end{tabular}

ROA beroepsgroepen van de belangrijkste ROA opleidingstypen, gemiddelde 2000-2001

$\begin{array}{crl}\text { MBO administratie } & \% & \text { trend 1997-2001 } \\ \text { Boekhouders en secretaresses } & 36 & \text { constant } \\ \text { Commercieel employés } & 11 & \text { constant } \\ \text { Receptionisten en administratieve employés } & 5 & \text { stijgend } \\ \text { Andere beroepsgroepen } & 47 & \\ & & \\ \text { MBO automatisering } & \% & \text { trend 1997-2001 } \\ \text { Programmeurs } & 38 & \text { stijgend } \\ \text { Systeemanalisten } & 10 & \text { dalend } \\ \text { Boekhouders en secretaresses } & 8 & \text { constant } \\ \text { Andere beroepsgroepen } & 44 & \end{array}$


Tabel 2.4

GOC (Kenniscentrum voor onderwijs, arbeidsmarkt en training \& advies in de grafimediabranche)

ROA opleidingstype

VMBO grafische techniek

MBO grafische techniek

grafisch assistent

grafisch management

multimedia vormgever

grafisch vormgever

grafisch intermediair

audiovisueel medewerker

boekbinder

uitgaafbinder

brocheerder

vellenbewerker

zeefdrukker

flexodrukker

diepdrukker

offsetdrukker

elektronisch voorbereider

verpakkingsoperator

basisnabewerker

basisdrukker

basisvoorbereider

it mediaproductie
VMBO grafische techniek MBO grafische techniek MBO grafische techniek MBO grafische techniek MBO grafische techniek MBO grafische techniek MBO grafische techniek MBO grafische techniek MBO grafische techniek MBO grafische techniek MBO grafische techniek MBO grafische techniek MBO grafische techniek MBO grafische techniek MBO grafische techniek MBO grafische techniek MBO grafische techniek MBO grafische techniek MBO grafische techniek MBO grafische techniek

ROA bedrijfssectoren van het belangrijkste ROA opleidingstype, gemiddelde 2000-2001

MBO grafische techniek

Grafische industrie

Zakelijke dienstverlening

Handel en reparatie

Andere bedrijfssectoren trend 1997-2001

dalend

dalend

constant

ROA beroepsgroepen van het belangrijkste ROA opleidingstype, gemiddelde 2000-2001

MBO grafische techniek

Grafische vakkrachten

Grafisch productiepersoneel

Grafisch ontwerpers

Commercieel employés

Andere beroepsgroepen trend 1997-2001

dalend

sterk stijgend

stijgend 
Tabel 2.5

INNOVAM (Het opleidings- en examencentrum van de mobiliteitsbranche)

ROA opleidingstype

VMBO voertuigentechniek

VMBO administratie, handel en mode

MBO motorvoertuigentechniek

MBO handel

assistent autotechnicus

verkoper tankstation

commercieel bedrijfsleider/ondernemer kleinbedrijf commercieel bedrijfsleider/ondernemer mobiele werktuigen diagnosetechnicus bedrijfsauto's

diagnosetechnicus personenauto's

commercieel bedrijfsleider/ondernemer middelgroot bedrijf

bedrijfsleider/ondernemer in de mvt-branche

eerste bedrijfsauto-elektrotechnicus

eerste auto-elektrotechnicus

werkplaatsmanager bedrijfsauto's

servicemanager bedrijfsauto's

werkplaatsmanager personenauto's

servicemanager personenauto's

onderdelenmanager

eerste motorfietstechnicus

eerste dieselmotortechnicus

eerste bedrijfsautotechnicus

eerste autotechnicus

onderdelenadviseur

auto-elektricien

autodemontagetechnicus

assemblagetechnicus

dieselmotortechnicus

revisietechnicus

motorfietstechnicus

bromfietstechnicus

fietstechnicus

bedrijfsautotechnicus

autotechnicus

verkoopleider bedrijfsauto's

verkoopleider personenauto's

verkoper bedrijfsauto's

verkoper bedrijfsauto's

verkoper personenauto's

eerste verkoper tankstation

verkoper personenauto's

eerste verkoper tankstation

praktijkinstructeur
VMBO voertuigentechniek

VMBO administratie, handel en mode

MBO motorvoertuigentechniek

MBO motorvoertuigentechniek

MBO motorvoertuigentechniek

MBO motorvoertuigentechniek

MBO motorvoertuigentechniek

MBO motorvoertuigentechniek

MBO motorvoertuigentechniek

MBO motorvoertuigentechniek

MBO motorvoertuigentechniek

MBO motorvoertuigentechniek

MBO motorvoertuigentechniek

MBO motorvoertuigentechniek

MBO motorvoertuigentechniek

MBO motorvoertuigentechniek

MBO motorvoertuigentechniek

MBO motorvoertuigentechniek

MBO motorvoertuigentechniek

MBO motorvoertuigentechniek

MBO motorvoertuigentechniek

MBO motorvoertuigentechniek

MBO motorvoertuigentechniek

MBO motorvoertuigentechniek

MBO motorvoertuigentechniek

MBO motorvoertuigentechniek

MBO motorvoertuigentechniek

MBO motorvoertuigentechniek

MBO motorvoertuigentechniek

MBO motorvoertuigentechniek

MBO handel

MBO handel

MBO handel

MBO handel

MBO handel

MBO handel

MBO handel

MBO handel

MBO overig 
Tabel 2.5 (vervolg)

INNOVAM (Het opleidings- en examencentrum van de mobiliteitsbranche)

ROA bedrijfssectoren van het belangrijkste ROA opleidingstype, gemiddelde 2000-2001

\begin{tabular}{ccl}
\hline MBO motorvoertuigentechniek & $\%$ & trend 1997-2001 \\
Handel en reparatie & 58 & stijgend \\
Weg- en railvervoer & 9 & dalend \\
Andere bedrijfssectoren & 33 & \\
\hline
\end{tabular}

ROA beroepsgroepen van het belangrijkste ROA opleidingstype, gemiddelde 20002001

MBO motorvoertuigentechniek

Monteurs

Chauffeurs

Assembleurs

Andere beroepsgroepen

5 constant


Tabel 2.6

INTECHNIUM (Het kennis- en technologiecentrum voor de installatietechniek)

ROA opleidingstype

VMBO installatietechniek

MBO bouw

MBO installatietechniek

MBO werktuigbouw en mechanische techniek

Crebo opleiding

ROA opleidingstype

montage-assistent verwarmingstechniek (masv)

montage-assistent installatietechniek (masi)

montage-assistent koudetechniek (mask)

montage-assistent distributietechniek (masd)

tekenaar gebouwinstallaties (tgisan)

tekenaar gebouwinstallaties (tgisan/cv/vent)

tekenaar gebouwinstallaties (tgicv/vent)

verwarmingsmonteur ( $\mathrm{vm})$

servicetechnicus (st)

servicemonteur verwarmingstechniek (semv)

servicemonteur installatietechniek (semi)

onderhoudsmonteur verwarmingstechniek (omv)

onderhoudsmonteur installatietechniek (omi)

installatiemonteur met specialisatie utiliteit (imu)

installatiemonteur met specialisatie woningbouw (imw)

installatiemonteur met specialisatie dakbedekking (imd)

dakbedekkingsmonteur(dakm)

assistent verwarmingsmonteur (avm)

aankomend projecttechnicus gebouwinstallaties (apgsan)

aankomend projecttechnicus gebouwinstallaties (apgsan/cv/ac)

aankomend ontwerptechnicus gebouwinstallaties (aogsan/cv/ac) aankomend ontwerptechnicus gebouwinstallaties (aogsan)

assistent installatiemonteur (aimv)

assistent installatiemonteur (aimdv)

assistent installatiemonteur (aimd)

assistent dakbedekkingsmonteur (adak)

middenkaderfunctionaris installatietechniek (mki)

servicemonteur koudetechniek (semk)

projectleider koudetechniek (plk)

monteur koudetechniek (mk)

distributiemonteur water (dmw)

distributiemonteur gas (dmg)

assistent distributiemonteur water (admw)

assistent distributiemonteur gas (admg)

middenkaderopleiding installatietechniek (koudetechniek)

middenkaderopleiding installatietechniek (klimaattechniek)

VMBO installatietechniek

VMBO installatietechniek

VMBO techniek overig

VMBO techniek overig

MBO bouw

MBO bouw

MBO bouw

MBO installatietechniek

MBO installatietechniek

MBO installatietechniek

MBO installatietechniek

MBO installatietechniek

MBO installatietechniek

MBO installatietechniek

MBO installatietechniek

MBO installatietechniek

MBO installatietechniek

MBO installatietechniek

MBO installatietechniek

MBO installatietechniek

MBO installatietechniek

MBO installatietechniek

MBO installatietechniek

MBO installatietechniek

MBO installatietechniek

MBO installatietechniek

MBO installatietechniek

MBO werktuigbouw en

mechanische techniek

MBO werktuigbouw en

mechanische techniek

MBO werktuigbouw en mechanische techniek MBO werktuigbouw en mechanische techniek MBO werktuigbouw en mechanische techniek $\mathrm{MBO}$ werktuigbouw en mechanische techniek MBO werktuigbouw en mechanische techniek MBO werktuigbouw en mechanische techniek MBO werktuigbouw en mechanische techniek 
Tabel 2.6 (vervolg)

INTECHNIUM (Het kennis- en technologiecentrum voor de installatietechniek)

Crebo opleiding

ROA opleidingstype

projectmanager koudetechniek (pmk)

MBO werktuigbouw en

mechanische techniek

MBO werktuigbouw en

middenkaderfunctionaris koudetechniek (mkk)

mechanische techniek

ROA bedrijfssectoren van de belangrijkste ROA opleidingstypen, gemiddelde 2000-2001

MBO werktuigbouw en mechanische techniek

trend 1997-2001

Machine-industrie

dalend

Metaalproducten

Handel en reparatie

Bouw

constant

Zakelijke dienstverlening

sterk stijgend

Transportmiddelen

constan

Andere bedrijfssectoren

stijgend

dalend

MBO installatietechniek

Bouw

Handel en reparatie

Andere bedrijfssectoren

trend 1997-2001

constant

sterk stijgend

ROA beroepsgroepen van de belangrijkste ROA opleidingstypen, gemiddelde 2000-2001

MBO installatietechniek

Aannemers en installateurs

Monteurs

Bouwvakkers

Andere beroepsgroepen

MBO werktuigbouw en mechanische techniek

Monteurs

Bankwerkers en lassers

Metaalarbeiders

Aannemers en installateurs

Andere beroepsgroepen trend 1997-2001

constant

stijgend

stijgend

trend 1997-2001

constant

constant

constant

constant 
Tabel 2.7

KC HANDEL (Kenniscentrum Handel)

ROA opleidingstype

VMBO administratie, handel en mode

MBO administratie

MBO handel

winkelassistent

opslag medewerker

orderpicker

winkelassistent

ondernemer groothandel

districtsmanager

hoofd magazijn

groepsleider magazijn

vertegenwoordiger

medewerker inkoop

commercieel medewerker binnendienst

exportmedewerker binnendienst

exportmedewerker buitendienst

assistent exportmanager

magazijn medewerker

ondernemer/manager detailhandel

ondernemer ambulante handel

ondernemer kleinbedrijf textielindustrie en -handel

filiaalbeheerder

verkoopchef

afdelingschef kassa

eerste verkoper

leidinggevende textielindustrie en -handel

verkoopmedewerker

verkoop medewerker ambulante handel

ondernemer kleinbedrijf textielindustrie en -handel mk bol

leidinggevende textielindustrie en -handel vk bol
VMBO administratie, handel en mode

VMBO administratie, handel

en mode

VMBO administratie, handel

en mode

VMBO administratie, handel

en mode

MBO administratie

MBO administratie

MBO administratie

MBO administratie

MBO administratie

MBO administratie

MBO administratie

MBO administratie

MBO administratie

MBO administratie

MBO administratie

MBO handel

$\mathrm{MBO}$ handel

MBO handel

MBO handel

MBO handel

MBO handel

MBO handel

MBO handel

MBO handel

$\mathrm{MBO}$ handel

MBO handel

$\mathrm{MBO}$ handel

ROA bedrijfssectoren van het belangrijkste ROA opleidingstype, gemiddelde 2000-2001

MBO handel

Handel en reparatie

Zakelijke dienstverlening

Andere bedrijfssectoren trend 1997-2001

constant

sterk stijgend 
Tabel 2.7 (vervolg)

KC HANDEL (Kenniscentrum Handel)

ROA beroepsgroepen van het belangrijkste ROA opleidingstype, gemiddelde 2000-2001

MBO handel

Winkeliers

Verkopers

Boekhouders en secretaresses

Commercieel employés

Commercieel medewerkers

Andere beroepsgroepen trend 1997-2001

constant

dalend

stijgend

constant

dalend 
Tabel 2.8

KOC Nederland (Kenniscentrum voor uiterlijke verzorging)

ROA opleidingstype

MBO uiterlijke verzorging

\begin{tabular}{|c|c|}
\hline Crebo opleiding & ROA opleidingstype \\
\hline $\begin{array}{l}\text { voetverzorging } \\
\text { schoonheidsspecialist } \\
\text { all-round kapper } \\
\text { all-round kapper } \\
\text { kapper } \\
\text { kapper } \\
\text { allround afro kapper } \\
\text { afro kapper }\end{array}$ & $\begin{array}{l}\text { MBO uiterlijke verzorging } \\
\text { MBO uiterlijke verzorging } \\
\text { MBO uiterlijke verzorging } \\
\text { MBO uiterlijke verzorging } \\
\text { MBO uiterlijke verzorging } \\
\text { MBO uiterlijke verzorging } \\
\text { MBO uiterlijke verzorging } \\
\text { MBO uiterlijke verzorging }\end{array}$ \\
\hline Bedrijfssector (SBI) volgens KBB & ROA Bedrijfssector \\
\hline Kappers en schoonheidsverzorging & $\begin{array}{l}\text { Overige commerciële } \\
\text { dienstverlening }\end{array}$ \\
\hline
\end{tabular}

ROA bedrijfssectoren van de belangrijkste ROA opleidingstypen, gemiddelde 2000-2001

\begin{tabular}{|c|c|c|}
\hline $\begin{array}{l}\text { MBO uiterlijke verzorging } \\
\text { Overige commerciële dienstverlening } \\
\text { Handel en reparatie } \\
\text { Gezondheidszorg } \\
\text { Andere bedrijfssectoren }\end{array}$ & $\begin{array}{r}\% \\
47 \\
21 \\
7 \\
25\end{array}$ & $\begin{array}{l}\text { trend 1997-2001 } \\
\text { constant } \\
\text { stijgend } \\
\text { sterk dalend }\end{array}$ \\
\hline Beroepsgroep (SBC) volgens KBB & \multicolumn{2}{|c|}{ ROA Beroepsgroep } \\
\hline $\begin{array}{l}\text { Kapper } \\
\text { Pedicure }\end{array}$ & \multicolumn{2}{|c|}{$\begin{array}{l}\text { Verzorgend personeel } \\
\text { Hulpkrachten horeca en } \\
\text { verzorging }\end{array}$} \\
\hline
\end{tabular}

ROA beroepsgroepen van de belangrijkste ROA opleidingstypen, gemiddelde 2000-2001

\begin{tabular}{lrl}
\hline MBO uiterlijke verzorging & & \\
Verzorgend personeel & $\%$ & trend 1997-2001 \\
Verkopers & 12 & constant \\
Boekhouders en secretaresses & 7 & - \\
Andere beroepsgroepen & 34 & \\
\hline
\end{tabular}


Tabel 2.9

Lift Groep (Het onderwijscentrum textiel en conferentie)

ROA opleidingstype

VMBO administratie, handel en mode

MBO techniek overig

MBO handel

Crebo opleiding

ROA opleidingstype

assistent medewerker naaizaal

assistent operator veredeling

assistent operator garenverwerking

assistent operator vezelverwerking

specialist veredeling

monteur mechanische verwerking

specialist mechanische verwerking

operator filament- en vezelvervaardiging

operator veredeling

operator garenverwerking

operator vliesstofvervaardiging

operator vezelverwerking

middenkader medewerker productie

middenkader medewerker ontwikkeling

middenkader medewerker commercie

medewerker grootvak maatkleding

eerste medewerker naai-/perszaal

eerste medewerker snijzaal

ondernemer/middenkader medewerker breedvak maatkleding

uitvoerend medewerker kleinvak maatkleding

uitvoerend medewerker naai-/perszaal

VMBO administratie, handel

en mode

VMBO administratie, handel

en mode

VMBO administratie, handel

en mode

VMBO administratie, handel

en mode

MBO techniek overig

MBO techniek overig

MBO techniek overig

MBO techniek overig

MBO techniek overig

MBO techniek overig

MBO techniek overig

MBO techniek overig

MBO handel

MBO handel

MBO handel

MBO handel

MBO handel

MBO handel

MBO handel

MBO handel

MBO handel

uitvoerend medewerker snijzaal

MBO handel

ROA bedrijfssectoren van de belangrijkste ROA opleidingstypen, gemiddelde 2000-2001

MBO handel

Handel en reparatie

Zakelijke dienstverlening

Andere bedrijfssectoren

trend 1997-2001

$\%$

constant

sterk stijgend

ROA beroepsgroepen van de belangrijkste ROA opleidingstypen, gemiddelde 2000-2001

$\begin{array}{ccl}\text { MBO handel } & \% & \text { trend 1997-2001 } \\ \text { Winkeliers } & 14 & \text { constant } \\ \text { Verkopers } & 14 & \text { dalend } \\ \text { Boekhouders en secretaresses } & 9 & \text { stijgend } \\ \text { Commercieel employés } & 9 & \text { constant } \\ \text { Commercieel medewerkers } & 5 & \text { dalend } \\ \text { Andere beroepsgroepen } & 49 & \end{array}$


Tabel 2.10

LOB HTV (Landelijk orgaan beroepsonderwijs horeca, toerisme en voeding)

ROA opleidingstype

VMBO brood en banket

VMBO consumptief en levensmiddelentechniek

MBO brood en banket

MBO horeca

MBO secretariaat

MBO toerisme en recreatie

Crebo opleiding

ROA opleidingstype

assistent bakker

horeca-assistent

specialist banketbakker

leidinggevende

specialist broodbakker

all-round banketbakker

all-round brood- en banketbakker

all-round broodbakker

banketbakker

brood- en banketbakker

broodbakker

banketbakker grootbedrijf

broodbakker grootbedrijf

leidinggevende grootbedrijf

all-round broodbakker grootbedrijf

leidinggevende

broodbakker grootwinkelbedrijf bb bbl

medewerker industriële bakkerij vk bbl

leidinggevende industriële bakkerij $\mathrm{mk}$ bol

leidinggevende bakkerij grootwinkelbedrijf $\mathrm{mk}$ bbl

ondernemer bakkersbedrijf $\mathrm{mk}$ bol

banketbakker grootwinkelbedrijf bb bbl

afdelingsmanager

horeca-ondernemer cafe/bar en fast food

restaurateur

horeca-ondernemer/-manager

gespecialiseerd kok

dieetkok

zelfstandig werkend gastheer/-vrouw

zelfstandig werkend kok

gastheer/gastvrouw

kok

bartender

fast food-specialist

receptionist

middenkaderfunctionaris recreatie

middenkaderfunctionaris recreatie $\mathrm{mk}$ bbl

middenkaderfunctionaris toeristische informatie

middenkaderfunctionaris reizen

zelfstandig werkend medewerker recreatie

zelfstandig werkend medewerker toeristische informatie

zelfstandig werkend medewerker reizen

zelfstandig werkend medewerker reizen vk bbl

VMBO brood en banket

VMBO consumptief en

levensmiddelentechniek

MBO brood en banket

MBO brood en banket

MBO brood en banket

MBO brood en banket

MBO brood en banket

MBO brood en banket

MBO brood en banket

MBO brood en banket

MBO brood en banket

MBO brood en banket

MBO brood en banket

MBO brood en banket

MBO brood en banket

MBO brood en banket

MBO brood en banket

MBO brood en banket

MBO brood en banket

MBO brood en banket

MBO brood en banket

MBO brood en banket

MBO horeca

MBO horeca

MBO horeca

MBO horeca

MBO horeca

MBO horeca

MBO horeca

MBO horeca

MBO horeca

MBO horeca

MBO horeca

MBO horeca

MBO secretariaat

MBO toerisme en recreatie

MBO toerisme en recreatie

MBO toerisme en recreatie

MBO toerisme en recreatie

MBO toerisme en recreatie

MBO toerisme en recreatie

$\mathrm{MBO}$ toerisme en recreatie

MBO toerisme en recreatie 
Tabel 2.10 (vervolg)

LOB HTV (Landelijk orgaan beroepsonderwijs horeca, toerisme en voeding)

$\begin{array}{ll}\text { Crebo opleiding } & \text { ROA opleidingstype }\end{array}$

medewerker reizen \& toeristische informatie

MBO toerisme en recreatie

$\mathrm{MBO}$ toerisme en recreatie

ROA bedrijfssectoren van de belangrijkste ROA opleidingstypen, gemiddelde 2000-2001

$\begin{array}{ccl}\text { MBO horeca } & \% & \text { trend 1997-2001 } \\ \text { Horeca } & 41 & \text { sterk stijgend } \\ \text { Handel en reparatie } & 12 & \text { constant } \\ \text { Gezondheidszorg } & 11 & \text { sterk dalend } \\ \text { Zakelijke dienstverlening } & 5 & \text { dalend } \\ \text { Andere bedrijfssectoren } & 31 & \\ \text { MBO toerisme en recreatie } & \% & \text { trend 1997-2001 } \\ \text { Weg- en railvervoer } & 33 & \text { dalend } \\ \text { Handel en reparatie } & 10 & \text { sterk stijgend } \\ \text { Zakelijke dienstverlening } & 9 & \text { sterk dalend } \\ \text { Bankwezen } & 7 & \text { sterk dalend } \\ \text { Overheid } & 7 & \text { sterk stijgend } \\ \text { Horeca } & 7 & \text { sterk stijgend } \\ \text { Andere bedrijfssectoren } & 26 & \\ \text { Mand } & & \\ \text { Overige voedingsproducten } & \% & \text { trend 1997-2001 } \\ \text { Handel en reparatie } & 44 & \text { dalend } \\ \text { Zakelijke dienstverlening } & 18 & \text { sterk stijgend } \\ \text { Andere bedrijfssectoren } & 5 & \text { sterk stijgend } \\ \text { MBO } & 33 & \end{array}$

ROA beroepsgroepen van de belangrijkste ROA opleidingstypen, gemiddelde 2000-2001

\begin{tabular}{ccl} 
MBO horeca & $\%$ & trend 1997-2001 \\
Verzorgend personeel & 24 & dalend \\
Bedrijfshoofden horeca & 14 & constant \\
Hulpkrachten horeca en verzorging & 9 & dalend \\
Boekhouders en secretaresses & 7 & sterk stijgend \\
Commercieel employés & 6 & sterk stijgend \\
Andere beroepsgroepen & 42 & trend 1997-2001 \\
& & - \\
MBO toerisme en recreatie & $\%$ & stijgend \\
Commercieel employés & 34 & - \\
Boekhouders en secretaresses & 19 & - \\
Receptionisten en administratieve employés & 13 & \\
Commercieel medewerkers & 7 & trend 1997-2001 \\
Andere beroepsgroepen & 27 & constant \\
brood en banket & \multicolumn{3}{l}{ sterk dalend } \\
Bakkers en slagers & 32 &
\end{tabular}


Tabel 2.11

Opleidingscentrum SVS (Opleidingscentrum voor het schilders- en stukadoorsbedrijf \& reclameen presentatietechnieken)

ROA opleidingstype

VMBO bouwtechniek

MBO bouw

assistent metaalconserveerder

assistent industriele lakverwerker

assistent schilder as bbl

chef lakkerij

vakkracht industriele lakverwerking metaal

vakkracht industriele lakverwerking hout

industriele lakverwerker metaal

industriele lakverwerker hout

metaalconserveerder

uitvoerder

restauratiestukadoor

gezel stukadoor

betonreparateur

dekvloerenlegger

monteur systeemwanden en -plafonds

stukadoor

ondernemer bescherming en afwerking

specialist wandafwerking

restauratieschilder

gezel schilder

gezel glaszetter

glaszetter

schilder

gezel glaszetter vk bbl

kaderfunctionaris bescherming en afwerking $\mathrm{mk}$ bo

glaszetter bb bbl

uitvoerder afbouw sp bbl

vormgever reclame, presentatie en communicatie

medewerker toegepaste vormgeving

specialist interieurafwerking
VMBO bouwtechniek

VMBO bouwtechniek

VMBO bouwtechniek

$\mathrm{MBO}$ bouw

MBO bouw

MBO bouw

MBO bouw

MBO bouw

MBO bouw

MBO bouw

MBO bouw

MBO bouw

MBO bouw

MBO bouw

MBO bouw

MBO bouw

MBO bouw

MBO bouw

MBO bouw

MBO bouw

MBO bouw

MBO bouw

MBO bouw

MBO bouw

MBO bouw

MBO bouw

MBO bouw

MBO handel

$\mathrm{MBO}$ handel

MBO handel

Bedrijfssector (SBI) volgens $K B B$

ROA Bedrijfssector

Afwerken van gebouwen

Bouw

ROA bedrijfssectoren van het belangrijkste ROA opleidingstype, gemiddelde 2000-2001

MBO bouw

Bouw

Hout- en bouwmaterialen

Zakelijke dienstverlening

Handel en reparatie

Andere bedrijfssectoren trend 1997-2001

constant

dalend

stijgend

stijgend 
Tabel 2.11 (vervolg)

Opleidingscentrum SVS (Opleidingscentrum voor het schilders- en stukadoorsbedrijf \& reclameen presentatietechnieken

Beroepsgroep (SBC) volgens KBB

assistent onderhoudsmedewerker

stukadoor, beton-, cement-, terrazzovloerenlegger, -afwerker monteur systeembouw

schilder-behanger

huisschilder, verfspuiter

glazenmaker, glaszetter

etaleur

glas in lood-zetter

reclame-, decoratieschilder

etaleur
ROA Beroepsgroep

Kantoorhulpen, inpakkers en

colporteurs

Bouwvakkers

Bouwvakkers

Bouwvakkers

Bouwvakkers

Bouwvakkers

Verzekeringsagenten

Aannemers en installateurs

Technisch- commercieel employés

Technisch- commerciee

employés

ROA beroepsgroepen van het belangrijkste ROA opleidingstype, gemiddelde 2000-2001

MBO bouw

Aannemers en installateurs

Bouwvakkers

Architecten en bouwkundig projectleiders

Andere beroepsgroepen trend 1997-2001

constant

constant

sterk stijgend 
Tabel 2.12

OVDB (Landelijk orgaan van het beroepsonderwijs gezondheidszorg, dienstverlening, welzijn en sport)

ROA opleidingstype

VMBO (uiterlijke) verzorging

MBO dokters-, tandarts- en dierenartsassistent

MBO apothekersassistent

$\mathrm{MBO}$ verpleging

MBO sociaal-cultureel

$\mathrm{MBO}$ verzorging

MBO beweging en therapie

MBO overig

Crebo opleiding

ROA opleidingstype

zorghulp

tandartsassistent

doktersassistent

apothekersassistent

verpleegkundige

sociaal dienstverlener

sociaal cultureel werker

sociaal pedagogisch werker

activiteitenbegeleider

sociaal pedagogisch werker 3 (spw 3 )

sociaal pedagogisch werker 4 (spw 4)

sociaal dienstverlener (sd)

sociaal cultureel werker (scw)

verzorgende

helpende

medewerker facilitaire dienstverlening, niveau 4

leidster kindercentra $\mathrm{m} / \mathrm{v}$

medewerker facilitaire dienstverlening, niveau 2

voedingsassistent

helpende welzijn (hw)

sport- en bewegingsleider

praktijkopleider

onderwijsassistent

VMBO (uiterlijke) verzorging

MBO dokters-, tandarts- en

dierenartsassistent

MBO dokters-, tandarts- en

dierenartsassistent

MBO apothekersassistent

$M B O$ verpleging

MBO sociaal-cultureel

MBO sociaal-cultureel

MBO sociaal-cultureel

MBO sociaal-cultureel

MBO sociaal-cultureel

MBO sociaal-cultureel

MBO sociaal-cultureel

MBO sociaal-cultureel

$\mathrm{MBO}$ verzorging

MBO verzorging

$\mathrm{MBO}$ verzorging

$M B O$ verzorging

MBO verzorging

$\mathrm{MBO}$ verzorging

MBO verzorging

MBO beweging en therapie

$\mathrm{MBO}$ overig

MBO overig

ROA bedrijfssectoren van de belangrijkste ROA opleidingstypen, gemiddelde 2000-2001

MBO sociaal-cultureel

Gezondheidszorg

Overheid

Handel en reparatie

Zakelijke dienstverlening

Andere bedrijfssectoren

trend 1997-2001

stijgend

sterk stijgend

dalend

dalend 
Tabel 2.12 (vervolg)

OVDB (Landelijk orgaan van het beroepsonderwijs gezondheidszorg, dienstverlening, welzijn en sport)

ROA bedrijfssectoren van de belangrijkste ROA opleidingstypen, gemiddelde 2000-2001

$\begin{array}{crl}\text { MBO verzorging } & \% & \text { trend 1997-2001 } \\ \text { Gezondheidszorg } & 68 & \text { constant } \\ \text { Handel en reparatie } & 8 & \text { dalend } \\ \text { Andere bedrijfssectoren } & 24 & \end{array}$

ROA beroepsgroepen van de belangrijkste ROA opleidingstypen, gemiddelde 2000-2001

$\begin{array}{ccc}\text { MBO sociaal-cultureel } & \% & \text { trend 1997-2001 } \\ \text { Verzorgend personeel } & 19 & \text { stijgend } \\ \text { Activiteitenbegeleiders en medewerkers arbeids- } & & \text { constant } \\ \text { bemiddeling } & 19 & - \\ \text { Boekhouders en secretaresses } & 9 & \text { sterk stijgend } \\ \text { Therapeuten en verpleegkundigen } & 6 & \\ \text { Andere beroepsgroepen } & 47 & \text { trend 1997-2001 } \\ & \% & \text { stijgend } \\ \text { MBO verzorging } & 27 & \text { dalend } \\ \text { Ziekenverzorgenden } & 21 & \text { stijgend } \\ \text { Verzorgend personeel } & 6 & \text { constant } \\ \text { Boekhouders en secretaresses } & 6 & \end{array}$


Tabel 2.13

SBW (Opleider voor de infrastructuur)

ROA opleidingstype

MBO grond-, weg- en waterbouw

MBO operationele techniek

middenkaderfunctionaris geodesie

middenkaderfunctionaris grond-, water- en wegenbouw

machinist funderingsmachines

machinist wegenbouwmachines

machinist grondverzetmachines

middenkaderfunctionaris machinale wegenbouw

machinist grond-, water- en wegenbouw

monteur gww-machines soma

monteur gww-machines

buizenlegger

aankomend buizenlegger

kabelwerker

waterbouwer

aankomend waterbouwer

rioleringswerker

aankomend rioleringswerker

wegenwerker

aankomend wegenwerker

straatmaker

aankomend straatmaker

machinist funderingsmachines $\mathrm{vk}$ bb

machinist wegenbouwmachines $\mathrm{vk} \mathrm{bb}$

machinist grondverzetmachines $\mathrm{vk}$ bbl

machinist torenkraan

machinist mobiele kraan

machinist torenkraan vk bbl

MBO grond-, weg- en waterbouw

MBO grond-, weg- en waterbouw

MBO grond-, weg- en waterbouw

MBO grond-, weg- en waterbouw

MBO grond-, weg- en waterbouw

MBO grond-, weg- en waterbouw

MBO grond-, weg- en waterbouw

MBO grond-, weg- en waterbouw

MBO grond-, weg- en waterbouw

MBO grond-, weg- en waterbouw

MBO grond-, weg- en waterbouw

MBO grond-, weg- en waterbouw

MBO grond-, weg- en waterbouw

MBO grond-, weg- en waterbouw

MBO grond-, weg- en waterbouw

MBO grond-, weg- en waterbouw

MBO grond-, weg- en waterbouw

MBO grond-, weg- en waterbouw

MBO grond-, weg- en waterbouw

MBO grond-, weg- en waterbouw

MBO grond-, weg- en waterbouw

MBO grond-, weg- en waterbouw

MBO grond-, weg- en waterbouw

MBO operationele techniek

MBO operationele techniek

MBO operationele techniek

MBO operationele techniek

ROA bedrijfssectoren van de belangrijkste ROA opleidingstypen, gemiddelde 2000-2001

MBO grond-. weg- en waterbouw

Bouw

Overheid

Zakelijke dienstverlening

Andere bedrijfssectoren

MBO operationele techniek

Bouw

Andere bedrijfssectoren
$\%$

40

25

12

24

$\%$

43

57 trend 1997-2001

stijgend

stijgend

sterk dalend

trend 1997-2001

stijgend 
Tabel 2.13 (vervolg)

SBW (Opleider voor de infrastructuur)

ROA beroepsgroepen van de belangrijkste ROA opleidingstypen, gemiddelde 2000-2001

MBO grond-. weg- en waterbouw

Weg- en waterbouwkundige vakkrachten

Aannemers en installateurs

Weg- en waterbouwkundige arbeiders

Weg- en waterbouwkundig ontwerpers en

projectleiders

Productiemedewerkers

Andere beroepsgroepen

MBO operationele techniek

Weg- en waterbouwkundige vakkrachten

Andere beroepsgroepen trend 1997-2001

constant

sterk stijgend

sterk dalend

17
8

6

37

trend 1997-2001

sterk stijgend 
Tabel 2.14

SH\&M (Stichting hout en meubel)

ROA opleidingstype

VMBO bouwtechniek

VMBO administratie, handel en mode

MBO bouw

MBO werktuigbouw en mechanische techniek

MBO handel

assistent verkoper wonen

montagemedewerker timmerindustrie

assistent machinaal houtbewerker

assistent bestekzoeker

vloerenstoffeerder

kaderfunctionaris timmerindustrie

kaderfunctionaris houthandel

allround machinaal houtbewerker timmer-/meubelindustrie

allround werkplaatstimmerman

allround bestekzoeker

allround machinaal houtbewerker houthandel

parketlegger

machinaal houtbewerker timmerindustrie/meubelindustrie

werkplaatstimmerman

bestekzoeker

machinaal houtbewerker houthandel

allround gereedschapslijper

gereedschapslijper

afdelingschef wonen

afdelingschef meubelstofferen

kaderfunctionaris meubel-/interieurbouwbedrijf

allround woningstoffeerder

verkoopadviseur wonen

meubelstoffeerder

allround meubelmaker / interieurbouwer / scheepsinterieurbouwer

woningstoffeerder

verkoper wonen

aankomend meubelstoffeerder

meubelmaker / interieurbouwer / scheepsinterieurbouwer
VMBO bouwtechniek

VMBO bouwtechniek

VMBO bouwtechniek

VMBO bouwtechniek

VMBO administratie, handel

en mode

MBO bouw

MBO bouw

MBO bouw

MBO bouw

MBO bouw

MBO bouw

MBO bouw

MBO bouw

MBO bouw

MBO bouw

MBO bouw

MBO werktuigbouw en

mechanische techniek

MBO werktuigbouw en

mechanische techniek

MBO handel

MBO handel

MBO handel

MBO handel

MBO handel

MBO handel

MBO handel

MBO handel

MBO handel

MBO handel

MBO handel
Vervaardigen van meubels

Timmeren

Groothandel in hout en bouwmaterialen

Detailhandel in parket- laminaat- en krukvloeren
Hout- en bouwmaterialen

Bouw

Handel en reparatie

Handel en reparatie 
Tabel 2.14 (vervolg)

SH\&M (Stichting hout en meubel)

ROA bedrijfssectoren van de belangrijkste ROA opleidingstypen, gemiddelde 2000-2001

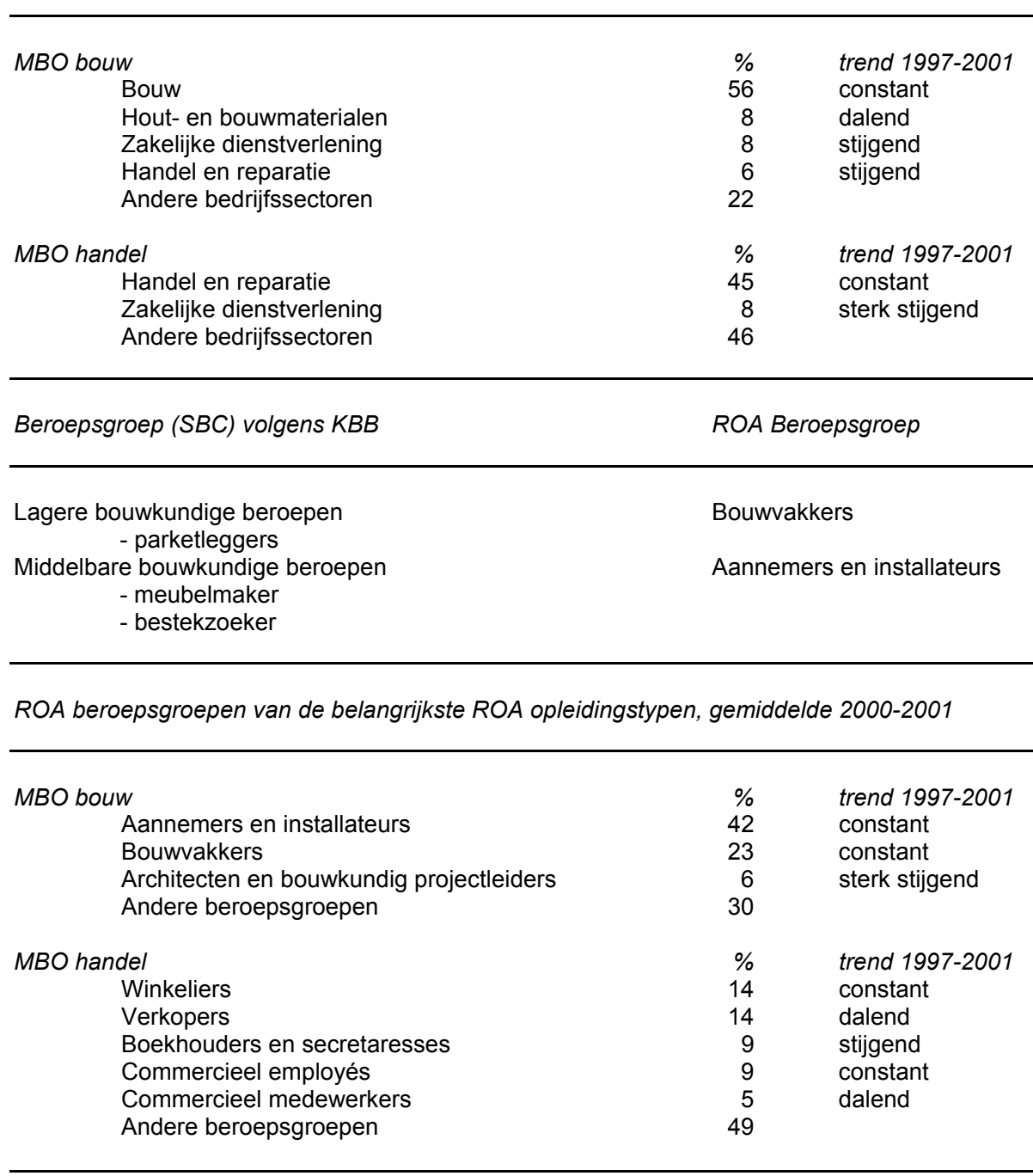


Tabel 2.15

SOM opleidingen metaal (Kenniscentrum beroepsonderwijs bedrijfsleven voor metaal en werktuigbouwkunde)

ROA opleidingstype

VMBO metaal: mechanische techniek

VMBO techniek overig

MBO werktuigbouw en mechanische techniek

MBO fijnmechanische techniek

MBO motorvoertuigentechniek

MBO vliegtuigtechniek

MBO operationele techniek

MBO elektrotechniek

MBO overig

Crebo opleiding

ROA opleidingstype

assistent bankwerker montage

assistent machinaal verspaner

productiemedewerker plaatwerken

assistent constructiewerker/lasser

aspirant-lasser

hoeklasser (ew) as bbl

assistent productietechnisch vakkracht

werktuigbouwkunde

modelmaker hout/kunststof

gieterijmedewerker

werktuigbouwkundig tekenaar/constructeur

werktuigbouwkundig tekenaar

aankomend werktuigbouwkundig tekenaar

onderhoudstechnicus werktuigbouw

eerste monteur landbouwmechanisatietechniek

eerste monteur industrieel onderhoud

monteur landbouwmechanisatietechniek

landbouwmachine-chauffeur/monteur

assemblage vakkracht

monteur montage/onderhoud

programmeur/verspaner cnc

slijper

machinaal verspaner

machinaal verspaner cnc

slijper

machinebankwerker werktuigbouw

machinaal verspaner

frezer

draaier

scheepsbouwer

opmeter/werkvoorbereider industriele isolatie

plaatwerker

constructie- en apparatenbouwer

scheepsmetaalbewerker

isoleerder/plaatwerker

pijpenbewerker

plaatwerker

forceur

bankwerker aluminium ramen

constructiebankwerker/lasser

constructiebankwerker/lasser bb bol
VMBO metaal: mechanische techniek

VMBO metaal: mechanische techniek

VMBO metaal: mechanische techniek

VMBO metaal: mechanische techniek

VMBO metaal: mechanische techniek

VMBO metaal: mechanische techniek

VMBO techniek overig

MBO werktuigbouw en mechanische techniek MBO werktuigbouw en mechanische techniek $\mathrm{MBO}$ werktuigbouw en mechanische techniek MBO werktuigbouw en mechanische techniek $\mathrm{MBO}$ werktuigbouw en mechanische techniek MBO werktuigbouw en mechanische techniek MBO werktuigbouw en mechanische techniek MBO werktuigbouw en mechanische techniek MBO werktuigbouw en mechanische techniek MBO werktuigbouw en mechanische techniek $\mathrm{MBO}$ werktuigbouw en mechanische techniek MBO werktuigbouw en mechanische techniek MBO werktuigbouw en mechanische techniek MBO werktuigbouw en mechanische techniek MBO werktuigbouw en mechanische techniek MBO werktuigbouw en mechanische techniek MBO werktuigbouw en mechanische techniek MBO werktuigbouw en mechanische techniek MBO werktuigbouw en mechanische techniek MBO werktuigbouw en mechanische techniek MBO werktuigbouw en mechanische techniek MBO werktuigbouw en mechanische techniek MBO werktuigbouw en mechanische techniek MBO werktuigbouw en mechanische techniek MBO werktuigbouw en mechanische techniek MBO werktuigbouw en mechanische techniek $\mathrm{MBO}$ werktuigbouw en mechanische techniek MBO werktuigbouw en mechanische techniek MBO werktuigbouw en mechanische techniek MBO werktuigbouw en mechanische techniek MBO werktuigbouw en mechanische techniek MBO werktuigbouw en mechanische techniek MBO werktuigbouw en mechanische techniek MBO werktuigbouw en mechanische techniek 
Tabel 2.15 (vervolg)

SOM opleidingen metaal (Kenniscentrum beroepsonderwijs bedrijfsleven voor metaal en werktuigbouwkunde)

plaat- en constructiewerker

metaalkunde

booglassen

lastechnicus (ewt)

plaatlasser (ew)

meesterlasser (ewp)

lasspecialist (ews)

pijplasser (ew)

draad- en zinkvonker

hoeklasser

plaatlasser

pijplasser

research-instrumentmaker optiek

research-instrumentmaker lasertechniek

research-instrumentmaker glas

research-instrumentenmaker metaal

fijnmechanische techniek

gereedschapmaker

instrumentmaker

graveur

machinebankwerker fijnmechanisch

monteur mobiel intern transport

vliegtuigonderhoudstechnicus avionica

vliegtuigonderhoudstechnicus mechanisch

vliegtuigbouwkunde

vliegtuigonderhoudsmonteur modificatie en reparatie

vliegtuigmonteur

vliegtuigonderhoudsmonteur

vliegtuigbouwer kunststoffen

vliegtuigbouwer metaal

bank- en plaatwerker vliegtuigbouwkunde

eerste productietechnisch vakkracht

productietechnisch vakkracht

onderhoudstechnicus elektro en instrumentatie

onderhoudstechnicus instrumentatie

onderhoudsmonteur elektro en instrumentatie

programmeur robots

installatiemonteur elektro en instrumentatie

petroleum, gas- en onderhoudstechniek

kaderfunctionaris

technisch bedrijfsleider metaal sp bbl

lasinstructeur (ews+)
MBO werktuigbouw en mechanische techniek MBO werktuigbouw en mechanische techniek $\mathrm{MBO}$ werktuigbouw en mechanische techniek MBO werktuigbouw en mechanische techniek MBO werktuigbouw en mechanische techniek $\mathrm{MBO}$ werktuigbouw en mechanische techniek MBO werktuigbouw en mechanische techniek MBO werktuigbouw en mechanische techniek MBO werktuigbouw en mechanische techniek MBO werktuigbouw en mechanische techniek MBO werktuigbouw en mechanische techniek MBO werktuigbouw en mechanische techniek MBO fijnmechanische techniek MBO fijnmechanische techniek MBO fijnmechanische techniek MBO fijnmechanische techniek MBO fijnmechanische techniek MBO fijnmechanische techniek MBO fijnmechanische techniek MBO fijnmechanische techniek MBO fijnmechanische techniek MBO motorvoertuigentechniek

MBO vliegtuigtechniek

MBO vliegtuigtechniek

MBO vliegtuigtechniek

MBO vliegtuigtechniek

MBO vliegtuigtechniek

MBO vliegtuigtechniek

MBO vliegtuigtechniek

MBO vliegtuigtechniek

MBO vliegtuigtechniek

MBO operationele techniek

MBO operationele techniek

MBO elektrotechniek

MBO elektrotechniek

MBO elektrotechniek

MBO elektrotechniek

MBO elektrotechniek

MBO techniek overig

MBO bedrijfskunde

MBO bedrijfskunde

MBO overig

ROA bedrijfssectoren van het belangrijkste ROA opleidingstype, gemiddelde 2000-2001

MBO werktuigbouw en mechanische techniek Machine-industrie

Metaalproducten

Handel en reparatie

Bouw

Zakelijke dienstverlening

Transportmiddelen trend 1997-2001

dalend

constant

sterk stijgend

constant

stijgend

dalend 
Tabel 2.15 (vervolg)

SOM opleidingen metaal (Kenniscentrum beroepsonderwijs bedrijfsleven voor metaal en werktuigbouwkunde)

ROA beroepsgroepen van het belangrijkste ROA opleidingstype, gemiddelde 2000-2001

Andere bedrijfssectoren

MBO werktuigbouw en mechanische techniek

Monteurs

Bankwerkers en lassers

Metaalarbeiders

Aannemers en installateurs

Andere beroepsgroepen
36

$\% \quad$ trend $1997-2001$

23 constant

17 constant

constant

constant 
Tabel 2.16

SVGB Onderwijscentrum (Stichting vakopleiding voor gezondheidstechnische en ambachtelijke beroepen)

ROA opleidingstype

VMBO administratie, handel en mode

VMBO (uiterlijke) verzorging

MBO fijnmechanische techniek

MBO brood en banket

MBO techniek overig

MBO verpleging

MBO gezondheidstechniek

MBO hande

assistent schoenhersteller

assistent schoenenverkoper

assistent schoenen \& lederwaren

orthopedisch technisch vakkracht

orthopedisch schoentechnisch vakkracht

verkoopmedewerker optiekbedrijf

graveur/ondernemer

graveur

juwelier/ondernemer

uurwerktechnicus/ondernemer

zilversmid/ondernemer

goudsmid/ondernemer

juwelier

uurwerktechnicus

zilversmid

goudsmid

aspirant juwelier

atelier uurwerktechnicus

productiemedewerker goud- en zilversmeden

aankomend graveur

gezel graveur

graveur/ondernemer

goudsmid specialist sp bbl

uurwerktechnicus specialist $\mathrm{sp}$ bol

leidinggevende ambachtelijke bakkerij $\mathrm{mk}$ bbl

gezel pianotechnicus

assistent pianotechnicus

ondernemer/manager orthopedisch instrumentmaker/ bandagist

ondernemer/manager orthopedisch schoentechniek

ondernemer/manager adaptietechnieken

opticien/ondernemer

specialist scoliose orthesen

specialist heup-, knie-, enkel-, voetprothesen

specialist armprothesen

paskamermedewerker orthopedisch/instrumentmaker en

-bandagist

orthopedisch bandagist
VMBO administratie, handel en

mode

VMBO administratie, handel en

mode

VMBO administratie, handel en

mode

VMBO (uiterlijke) verzorging

VMBO (uiterlijke) verzorging

VMBO (uiterlijke) verzorging

MBO fijnmechanische techniek

MBO fijnmechanische techniek

MBO fijnmechanische techniek

MBO fijnmechanische techniek

MBO fijnmechanische techniek

MBO fijnmechanische techniek

MBO fijnmechanische techniek

MBO fijnmechanische techniek

MBO fijnmechanische techniek

MBO fijnmechanische techniek

MBO fijnmechanische techniek

MBO fijnmechanische techniek

MBO fijnmechanische techniek

MBO fijnmechanische techniek

MBO fijnmechanische techniek

MBO fijnmechanische techniek

MBO fijnmechanische techniek

MBO fijnmechanische techniek

MBO brood en banket

MBO techniek overig

MBO techniek overig

MBO verpleging

$M B O$ verpleging

$M B O$ verpleging

$M B O$ verpleging

MBO gezondheidstechniek

MBO gezondheidstechniek

MBO gezondheidstechniek

MBO gezondheidstechniek MBO gezondheidstechniek 
Tabel 2.16 (vervolg)

SVGB Onderwijscentrum (Stichting vakopleiding voor gezondheidstechnische en ambachtelijke beroepen)

Crebo opleiding ROA opleidingstype

orthopedisch instrumentmaker

assistent orthopedisch bandagist

assistent orthopedisch instrumentenmaker

orthopedisch schoentechnicus

paskamermedewerker orthopedische schoentechniek vervaardiger orthopedische voorzieningen onderbeen/ voet

adaptietechnicus auto-aanpassingen

adaptietechnicus algemeen

tandprotheticus

manager/ondernemer tandtechnicus

specialist orthodontie

specialist kroon- en brugwerk

specialist partiele prothese

specialist volledige prothese

tandtechnicus

assistent tandtechnicus

opticien

assistent opticien

vakbekwaam audicien

assistent audicien

adaptatie-adviseur

adaptatietechnicus vk bbl

specialist aanpassingen aan confectieschoenen

ondernemer/manager schoenherstellersbedrijf

schoenconsulent

ondernemer/manager schoendetailhandelbedrijf

vakbekwaam hersteller schoenen en lederwaren

hoofdverkoper schoendetailhandel

gezel hersteller schoenen en lederwaren

verkoopmedewerker schoendetailhandel

kaderfunctionaris schoenen en lederwaren

industrieel lederwarenvervaardiger

ontwerper modelleur

industrieel schoenmaker

tassenvervaardiger

klein lederwarenvervaardiger

assembleur

stikker

stanzer

onderwerkmaker

schachtenmaker

leestenmaker
MBO gezondheidstechniek

MBO gezondheidstechniek

MBO gezondheidstechniek

MBO gezondheidstechniek

MBO gezondheidstechniek

MBO gezondheidstechniek

MBO gezondheidstechniek

MBO gezondheidstechniek

MBO gezondheidstechniek

MBO gezondheidstechniek

MBO gezondheidstechniek

MBO gezondheidstechniek

MBO gezondheidstechniek

MBO gezondheidstechniek

MBO gezondheidstechniek

MBO gezondheidstechniek

MBO gezondheidstechniek

MBO gezondheidstechniek

MBO gezondheidstechniek

MBO gezondheidstechniek

MBO gezondheidstechniek

MBO gezondheidstechniek

MBO handel

MBO handel

MBO handel

MBO handel

MBO handel

MBO handel

MBO handel

MBO handel

MBO handel

MBO handel

MBO handel

MBO handel

MBO handel

MBO handel

MBO handel

MBO handel

MBO handel

MBO handel

MBO handel

MBO handel

ROA bedrijfssectoren van de belangrijkste ROA opleidingstypen, gemiddelde 2000-2001

MBO gezondheidstechniek

Handel en reparatie

Andere bedrijfssectoren trend 1997-2001

sterk stijgend 
Tabel 2.16 (vervolg)

SVGB Onderwijscentrum (Stichting vakopleiding voor gezondheidstechnische en ambachtelijke beroepen)

ROA beroepsgroepen van de belangrijkste ROA opleidingstypen, gemiddelde 2000-2001

$\begin{array}{ccl}\text { MBO fijnmechanische techniek } & \% & \text { trend 1997-2001 } \\ \text { Handel en reparatie } & 31 & \text { dalend } \\ \text { Andere bedrijfsectoren } & 69 & \\ \text { MBO gezondheidstechniek } & \% & \text { trend 1997-2001 } \\ \text { Apothekersassistenten en medisch laboranten } & 74 & \text { constant } \\ \text { Andere beroepsgroepen } & 26 & \\ & \% & \text { trend 1997-2001 } \\ \text { constant }\end{array}$


Tabel 2.17

SVO (Kennis- en opleidingscentrum voor de foodsector)

ROA opleidingstype

VMBO consumptief en levensmiddelentechniek

MBO levensmiddelentechniek/vleesverwerking

Crebo opleiding

ROA opleidingstype

produktie-assistent vleesbe- en

-verwerkende industrie

assistent islamitische slagerij

assistent medewerker versdetailhandel

productie-assistent versindustrie

leidinggevende vleesbe- en

-verwerkende industrie

produktievakkracht vleesbe- en

-verwerkende industrie

produktiemedewerker vleesbe- en

-verwerkende industrie

islamitische slager

medewerker islamitische slagerij

manager vleesdetailhandel

chef vleesdetailhandel

traiteur

vleeswarenbereider

vleesbewerker

winkelslager

produktiemedewerker vleesbe- en

-verwerkende detailhandel

verkoopmedewerker vleesdetailhandel

medewerker versdetailhandel

productiemedewerker versindustrie

versspecialist detailhandel

productievakkracht versindustrie

manager versdetailhandel

leidinggevende versindustrie

VMBO consumptief en levensmiddelentechniek

VMBO consumptief en levensmiddelentechniek

VMBO consumptief en levensmiddelentechniek

VMBO consumptief en levensmiddelentechniek

MBO levensmiddelentechniek/vleesverwerking

MBO levensmiddelentechniek/vleesverwerking

MBO levensmiddelentechniek/vleesverwerking

MBO levensmiddelentechniek/vleesverwerking

MBO levensmiddelentechniek/vleesverwerking

MBO levensmiddelentechniek/vleesverwerking

MBO levensmiddelentechniek/vleesverwerking

MBO levensmiddelentechniek/vleesverwerking

MBO levensmiddelentechniek/vleesverwerking

MBO levensmiddelentechniek/vleesverwerking

MBO levensmiddelentechniek/vleesverwerking

MBO levensmiddelentechniek/vleesverwerking

MBO levensmiddelentechniek/vleesverwerking

MBO levensmiddelentechniek/vleesverwerking

MBO levensmiddelentechniek/vleesverwerking

MBO levensmiddelentechniek/vleesverwerking

MBO levensmiddelentechniek/vleesverwerking

MBO levensmiddelentechniek/vleesverwerking

MBO levensmiddelentechniek/vleesverwerking

ROA bedrijfssectoren van het belangrijkste ROA opleidingstype, gemiddelde 2000-2001

MBO levensmiddelentechniek/vleesverwerking

trend 1997-2001

Handel en reparatie

Overige voedingsproducten

Vlees- en visverwerking

Zakelijke dienstverlening

Andere bedrijfssectoren

sterk stijgend

sterk dalend

sterk stijgend 
Tabel 2.17 (vervolg)

SVO (Kennis- en opleidingscentrum voor de foodsector)

ROA beroepsgroepen van het belangrijkste ROA opleidingstype, gemiddelde 2000-2001

MBO levensmiddelentechniek/vleesverwerking

Mechanisch operators

Procesoperators

Bakkers en slagers

Andere beroepsgroepen

trend 1997-2001

dalend

constant

dalend 
Tabel 2.18

VT en L (Vakopleiding transport en logistiek)

ROA opleidingstype

VMBO transport en logistiek

MBO grond-, weg- en waterbouw

MBO werktuigbouw en mechanische techniek

MBO vervoer en logistiek

Crebo opleiding

ROA opleidingstype

assistent operationeel medewerker transport en logistiek assistent operationeel medewerker op- en overslag

baggeraar (baggerbedrijf)

baggeraar/machinist (baggerbedrijf)

baggeraar/stuurman (baggerbedrijf)

bakschipper/dekknecht (baggerbedrijf)

scheepsbouwkundige (scheepsbouw)

scheepstechnicus (zeevaart)

werktuigkundig monteur

maritiem officier (zeevaart)

stuurman/werktuigkundige zeevisvaart sw6

stuurman/werktuigkundige kleine schepen (zeevaart)

stuurman/werktuigkundige zeevisvaart sw5

schipper/machinist beperkt werkgebied

stuurman/werktuigkundige zeevisvaart sw-iv

kapitein

stuurman/schipper

matroos

bootman

luchtvaartdienstverlener

luchtvaartlogisticus

manager opslag en vervoer

specialist gevaarlijke stoffen

transportmanager

warehousemanager

voorman verhuizen

veiligheidsadviseur

planner wegtransport

expeditie planner

warehouse voorman

verhuizer

truckmixerchauffeur

particulier begeleider exceptioneel transport

chauffeur kipautovervoer

chauffeur geconditioneerd transport

chauffeur veetransport

chauffeur exceptioneel transport

chauffeur autotransport

autolaadkraanmachinist

chauffeur afvalstoffen

chauffeur goederenvervoer

chauffeur goederenvervoer

warehouse medewerker
VMBO transport en logistiek VMBO transport en logistiek

MBO grond-, weg- en waterbouw

MBO grond-, weg- en waterbouw

MBO grond-, weg- en waterbouw

MBO grond-, weg- en waterbouw

$\mathrm{MBO}$ werktuigbouw en

mechanische techniek

MBO werktuigbouw en

mechanische techniek

MBO werktuigbouw en

mechanische techniek

MBO vervoer en logistiek

MBO vervoer en logistiek

MBO vervoer en logistiek

MBO vervoer en logistiek

$\mathrm{MBO}$ vervoer en logistiek

MBO vervoer en logistiek

MBO vervoer en logistiek

MBO vervoer en logistiek

MBO vervoer en logistiek

$M B O$ vervoer en logistiek

MBO vervoer en logistiek

MBO vervoer en logistiek

MBO vervoer en logistiek

MBO vervoer en logistiek

MBO vervoer en logistiek

MBO vervoer en logistiek

MBO vervoer en logistiek

MBO vervoer en logistiek

MBO vervoer en logistiek

MBO vervoer en logistiek

MBO vervoer en logistiek

MBO vervoer en logistiek

MBO vervoer en logistiek

MBO vervoer en logistiek

MBO vervoer en logistiek

MBO vervoer en logistiek

MBO vervoer en logistiek

$\mathrm{MBO}$ vervoer en logistiek

MBO vervoer en logistiek

MBO vervoer en logistiek

MBO vervoer en logistiek

MBO vervoer en logistiek

MBO vervoer en logistiek

MBO vervoer en logistiek 
Tabel 2.18 (vervolg)

VT en L (Vakopleiding transport en logistiek)

Crebo opleiding

ROA opleidingstype

koerier

manager haven, vervoer en logistiek

cargadoor

expediteur

assistent-cargadoor

assistent-expediteur

technisch administratief medewerker

kaderfunctionaris in haven- en vervoerbedrijven

gevorderd operationeel medewerker op- en overslag

operationeel medewerker op- en overslag

aviation operations officer mk bol

medewerker goederenontvangst en voorraadbeheer

medewerker orderverzamelen en goederenuitlevering

acquisiteur

toerwagenchauffeur/reisleider

ondernemingsmanager

MBO vervoer en logistiek

$\mathrm{MBO}$ vervoer en logistiek

MBO vervoer en logistiek

MBO vervoer en logistiek

$\mathrm{MBO}$ vervoer en logistiek

MBO vervoer en logistiek

MBO vervoer en logistiek

MBO vervoer en logistiek

MBO vervoer en logistiek

$\mathrm{MBO}$ vervoer en logistiek

$M B O$ vervoer en logistiek

MBO administratie

MBO administratie

MBO administratie

MBO toerisme en recreatie

MBO bedrijfskunde

Bedrijfssector (SBI) volgens $K B B$

ROA Bedrijfssector

Vervoer over land

Vervoer over water

Vervoer door de lucht

Dienstverlening tbv het vervoer
Weg- en railvervoer

Scheeps- luchtvaart

Scheeps- luchtvaart

Weg- en railvervoer

ROA bedrijfssectoren van de belangrijkste ROA opleidingstypen, gemiddelde 2000-2001

MBO vervoer en logistiek

Weg- en railvervoer

Handel en reparatie

Onderwijs

Scheep- en luchtvaart

Andere bedrijfssectoren trend 1997-2001

stijgend

sterk stijgend

sterk stijgend

sterk dalend

ROA beroepsgroepen van de belangrijkste ROA opleidingstypen, gemiddelde 2000-2001

$\begin{array}{ccl}\text { MBO vervoer en logistiek } & \% & \text { trend 1997-2001 } \\ \text { Chauffeurs } & 19 & \text { constant } \\ \text { Productieplanners } & 9 & \text { sterk stijgend } \\ \text { Schippers en conducteurs } & 8 & \text { constant } \\ \text { Administratieve transportemployés } & 8 & - \\ \text { Monteurs } & 6 & \text { constant } \\ \text { Rij-instructeurs } & 6 & - \\ \text { Boekhouders en secretaresses } & 5 & \text { sterk stijgend } \\ \text { Laders en lossers } & 5 & \text { stijgend } \\ \text { Andere beroepsgroepen } & 33 & \end{array}$


Tabel 2.19

VaPro-OVP (Stichting vakopleiding procesindustrie)

ROA opleidingstype

VMBO landbouw en natuurlijke omgeving

VMBO techniek overig

MBO milieu en groene ruimte

MBO laboratorium

MBO fijnmechanische techniek

MBO operationele techniek

MBO grafische techniek

MBO procestechniek

MBO brood en banket

MBO openbare orde en veiligheid

uitvoerend milieumedewerker

basisoperator

middenkaderfunctionaris milieutechniek

middenkaderfunctionaris medische laboratoriumtechniek middenkaderfunctionaris chemische laboratoriumtechniek middenkaderfunctionaris biologische laboratoriumtechniek vakfunctionaris medische laboratoriumtechniek vakfunctionaris chemische laboratoriumtechniek vakfunctionaris biotechniek

vakfunctionaris biologische laboratoriumtechniek proefdierverzorger

vakfunctionaris biotechniek

vakfunctionaris medische laboratoriumtechniek

middenkaderfunctionaris biologische laboratoriumtechniek middenkaderfunctionaris medische laboratoriumtechniek

middenkaderfunctionaris chemische laboratoriumtechniek

middenkaderfunctionaris materiaaltechnologie

middenkaderfunctionaris laboratoriumtechniek

vakfunctionaris laboratoriumtechniek

operationele techniek

mechanisch operator $c$

mechanisch operator $b$

mechanisch operator a

middenkaderfunctionaris algemene operationele techniek medewerker algemene operationele techniek

middenkaderfunctionaris fotonica

medewerker beeldtechnieken

laborant

middenkaderfuctionaris procestechniek

procesoperator $\mathrm{c}$

procesoperator $b$

procesoperator a

laborant

operator a

basisveiligheid

veiligheid voor leidinggevenden
VMBO landbouw en natuurlijke omgeving

VMBO techniek overig

MBO milieu en groene ruimte

MBO laboratorium

MBO laboratorium

MBO laboratorium

MBO laboratorium

MBO laboratorium

MBO laboratorium

MBO laboratorium

MBO laboratorium

MBO laboratorium

MBO laboratorium

MBO laboratorium

MBO laboratorium

MBO laboratorium

MBO laboratorium

MBO fijnmechanische techniek

MBO fijnmechanische techniek

MBO operationele techniek

MBO operationele techniek

MBO operationele techniek

MBO operationele techniek

MBO operationele techniek

MBO operationele techniek

MBO grafische techniek

MBO grafische techniek

MBO procestechniek

MBO procestechniek

MBO procestechniek

MBO procestechniek

MBO procestechniek

MBO procestechniek

MBO brood en banket

MBO openbare orde en veiligheid

$\mathrm{MBO}$ openbare orde en veiligheid 
Tabel 2.19 (vervolg)

VaPro-OVP (Stichting vakopleiding procesindustrie)

ROA bedrijfssectoren van de belangrijkste ROA opleidingstypen, gemiddelde 2000-2001

\begin{tabular}{ccl} 
MBO procestechniek & $\%$ & trend 1997-2001 \\
Basischemie & 27 & constant \\
Basismetaal & 8 & stijgend \\
Eindproducten chemie & 8 & dalend \\
Overige voedingsproducten & 7 & stijgend \\
Energie & 7 & stijgend \\
Handel en reparatie & 6 & sterk stijgend \\
Elektrotechniek & 6 & \\
Andere bedrijfssectoren & 32 & \\
& & trend 1997-2001 \\
MBO laboratorium & $\%$ & sterk dalend \\
Gezondheidszorg & 25 & sterk stijgend \\
Eindproducten chemie & 11 & constant \\
Handel en reparatie & 8 & constant \\
Overheid & 7 & \\
Overige kwartaire diendend \\
Andere bedrijfssectoren & 6 & \\
\hline
\end{tabular}

ROA beroepsgroepen van de belangrijkste ROA opleidingstypen, gemiddelde 2000-2001

$\begin{array}{crl}\text { MBO procestechniek } & \% & \text { trend 1997-2001 } \\ \text { Procesoperators } & 43 & \text { constant } \\ \text { Mechanisch operators } & 9 & \text { sterk stijgend } \\ \text { Andere beroepsgroepen } & 47 & \\ & \% & \text { trend 1997-2001 } \\ \text { MBO laboratorium } & 24 & - \\ \text { Laboranten } & 19 & - \\ \text { Apothekersassistenten en medisch laboranten } & 6 & \text { sterk stijgend } \\ \text { Boekhouders en secretaresses } & 51 & -\end{array}$


Tabel 2.20

VEV (Vereniging elektronisch vakonderwijs)

ROA opleidingstype

VMBO techniek overig

MBO vliegtuigtechniek

MBO elektrotechniek

MBO automatisering

Crebo opleiding

ROA opleidingstype

assistent monteur montage elektronica componenten (amme) assistent monteur assemblage elektro componenten (amae)

assistent monteur nieuwbouwinstallaties (amni)

assistent monteur laagspanningsnetten (amln)

assistent monteur sterkstroominstallaties (amsi)

assistent monteur elektrische vliegtuiginstallaties (amvi)

middenkaderfunctionaris vliegtuigelektronicatechniek (mk-vet)

eerste monteur elektrische vliegtuiginstallaties (emvi)

monteur elektrische vliegtuiginstallaties (mvi)

middenkaderfunctionaris telematica (mk-tma)

technicus communicatiesystemen (tcs)

middenkaderfunctionaris automatiserings elektronica (mk-aec)

technicus consumentenelektronica (tce)

middenkaderfunctionaris automatiserings energietechniek

(mk-aen)

technicus elektrische bedrijfsinstallaties (tbi)

middenkaderf. elektrotechnische install. techniek (mk-eit)

technicus sterkstroominstallaties (tsi)

technicus middenspanningsinstallaties (tmi)

eerste monteur communicatienetten (emcn)

eerste monteur communicatie-installaties (emci)

eerste monteur consumentenelektronica (emce)

eerste monteur industriele elektronica (emie)

eerste monteur witgoedapparaten (emwa)

eerste monteur elektrotechnische panelen (emep)

eerste monteur elektro en instrumentatie (emei)

eerste monteur elektrische bedrijfsinstallaties (embi)

eerste monteur sterkstroominstallaties (emsi)

eerste monteur middenspanningsinstallaties (emmi)

eerste monteur laagspanningsnetten (emln)

monteur communicatienetten $(\mathrm{mcn})$

monteur communicatie-installaties (mci)

monteur consumentenelektronica (mce)

monteur industriele elektronica (mie)

monteur witgoedapparaten (mwa)

monteur elektrotechnisch wikkelen (mew)

monteur elektrotechnische panelen (mep)

monteur elektrische bedrijfsinstallaties (mbi)

monteur sterkstroominstallaties (msi)

monteur middenspanningsinstallaties (mmi)

monteur laagspanningsnetten $(\mathrm{mln})$

middenkaderfunct. kantoor automatiseringstechniek (mk-tka)

middenkaderfunct. productie automatiseringstechniek (mk-tpa)

middenkaderfuctionaris computer interfacetechniek (mk-cit)

ict-beheerder $\mathrm{mk} \mathrm{bbl}$

medewerker beheer ict vk bol

VMBO elektrotechniek

VMBO elektrotechniek

VMBO elektrotechniek

VMBO elektrotechniek

VMBO elektrotechniek

VMBO techniek overig

MBO vliegtuigtechniek

MBO vliegtuigtechniek

MBO vliegtuigtechniek

MBO elektrotechniek

MBO elektrotechniek

MBO elektrotechniek

MBO elektrotechniek

MBO elektrotechniek

MBO elektrotechniek

MBO elektrotechniek

MBO elektrotechniek

MBO elektrotechniek

MBO elektrotechniek

MBO elektrotechniek

MBO elektrotechniek

MBO elektrotechniek

MBO elektrotechniek

MBO elektrotechniek

MBO elektrotechniek

MBO elektrotechniek

MBO elektrotechniek

MBO elektrotechniek

MBO elektrotechniek

MBO elektrotechniek

MBO elektrotechniek

MBO elektrotechniek

MBO elektrotechniek

MBO elektrotechniek

MBO elektrotechniek

MBO elektrotechniek

MBO elektrotechniek

MBO elektrotechniek

MBO elektrotechniek

MBO elektrotechniek

MBO automatisering

MBO automatisering

MBO automatisering

MBO automatisering

MBO automatisering 
Tabel 2.20 (vervolg)

VEV (Vereniging elektronisch vakonderwijs)

Bedriffssector (SBI) volgens KBB

ROA Bedrijfssector

service medewerker-ict bb bbl

Vervaardiging van machines en apparaten

Vervaardiging van kantoormachines en computers

Vervaardiging van overige elektrische machines

Vervaardiging van audio-, video-, en telecommunicatie app.

Vervaardiging van transportmiddelen

Productie en distributie van elektr., aardgas,stoom,warm water
MBO automatisering

Machineindustrie

Elektrotechniek

Elektrotechniek

Elektrotechniek

Transportmiddelen

Energie

ROA bedrijfssectoren van de belangrijkste ROA opleidingstypen, gemiddelde 2000-2001

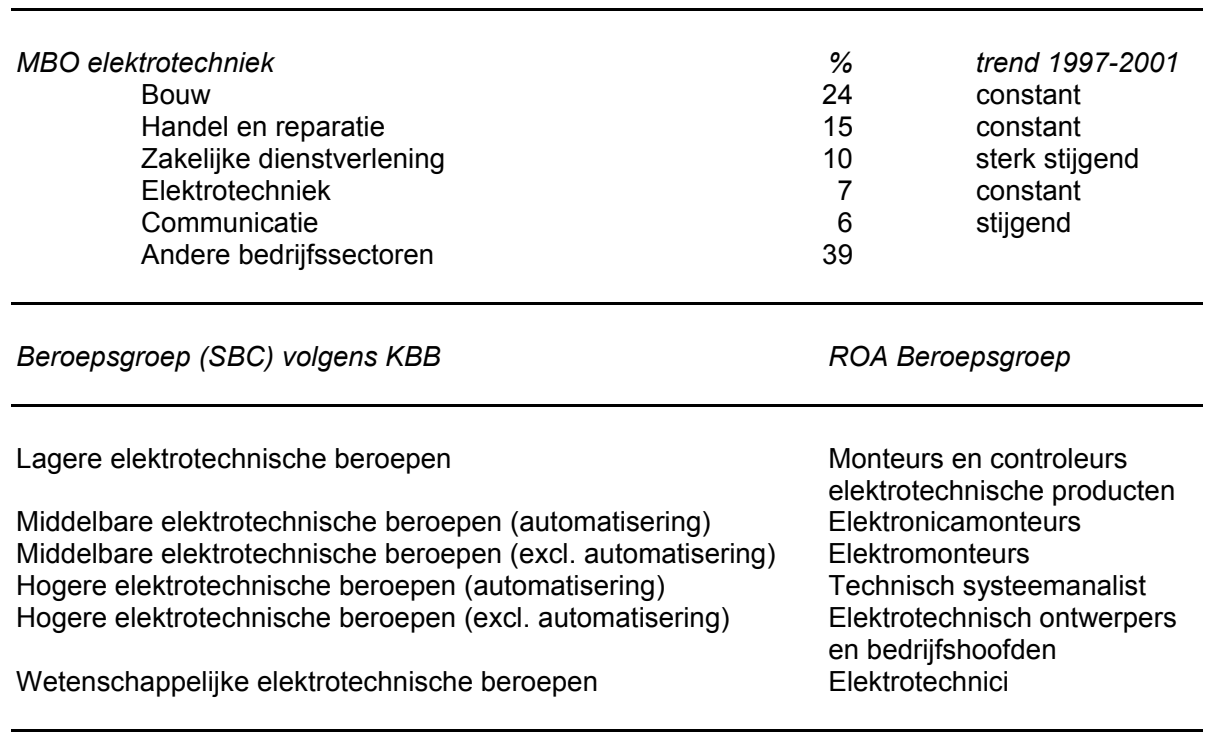

ROA beroepsgroepen van de belangrijkste ROA opleidingstypen, gemiddelde 2000-2001

$\begin{array}{ccl}\text { MBO elektrotechniek } & \% & \text { trend 1997-2001 } \\ \text { Elektromonteurs } & 26 & \text { dalend } \\ \text { Monteurs } & 13 & \text { dalend } \\ \text { Programmeurs } & 7 & \text { sterk stijgend } \\ \text { Andere beroepsgroepen } & 54 & \end{array}$


Tabel 2.21

VOC (Stichting vakopleiding carosseriebedrijf)

ROA opleidingstype

VMBO voertuigentechniek

MBO motorvoertuigentechniek

Crebo opleiding

ROA opleidingstype

aankomend voorbewerker

middenkaderfunctionaris carosseriebedrijf

VMBO voertuigentechniek

MBO motorvoertuigentechniek

middenkaderf. autoschadeherstelbedrijf c.q. autospuitbedrijf MBO motorvoertuigentechniek

eerste autospuiter

eerste autoschadehersteller

eerste caravanhersteller

MBO motorvoertuigentechniek

MBO motorvoertuigentechniek

eerste carrosseriebouwer

MBO motorvoertuigentechniek

MBO motorvoertuigentechniek

carosseriebouwer

MBO motorvoertuigentechniek

autospuiter

voertuiginterieurbouwer

autoschadehersteller

BO motorvoertuigentechniek

MBO motorvoertuigentechniek

MBO motorvoertuigentechniek

caravanhersteller

MBO motorvoertuigentechniek

Bedrijfssector (SBI) volgens KBB

ROA Bedrijfssector

Vervaardiging van auto's (incl. autobussen)

Transportmiddelen

Carrosseriebouw (incl. vervaardiging caravans) en

vervaardiging van aanhangwagens en opleggers

Carrosserieherstel personenauto's en bedrijfsauto's

Transportmiddelen

Handel en reparatie

Detailhandel (evt. in combinatie met reparatie) in caravans Handel en reparatie

ROA bedrijfssectoren van de belangrijkste ROA opleidingstypen, gemiddelde 2000-2001

MBO motorvoertuigentechniek

Handel en reparatie

Weg- en railvervoer

Andere bedrijfssectoren

Beroepsgroep (SBC) volgens KBB

ROA Beroepsgroep

Autoplaatwerker en autospuiter

Monteurs

Carrosseriebouwer

Monteurs

Caravanherstellers

Monteurs 
Tabel 2.21 (vervolg)

VOC (Stichting vakopleiding carosseriebedrijf)

ROA beroepsgroepen van de belangrijkste ROA opleidingstypen, gemiddelde 2000-2001

MBO motorvoertuigentechniek

Monteurs

Chauffeurs

Assembleurs

Andere beroepsgroepen

trend 1997-2001

constant

constant

constant 



\section{Belangrijkste beroepsgroepen}

Tabel 3.1

Belangrijkste beroepsgroepen per opleidingstype, gemiddelde 2000-2001

VMBO landbouw en natuurlijke omgeving Agrarische bedrijfshoofden Agrarische arbeiders

Chauffeurs

Andere beroepsgroepen

VMBO bouwtechniek

Bouwvakkers

Aannemers en installateurs

Chauffeurs

Andere beroepsgroepen

VMBO installatietechniek

Aannemers en installateurs

Andere beroepsgroepen

VMBO metaal: mechanische techniek

Metaalarbeiders

Monteurs

Chauffeurs

Aannemers en installateurs

Bouwvakkers

Andere beroepsgroepen

dalend

constant

constant

47

constant

stijgend

constant

stijgend

(n)

constant

constant

constant

constant

constant

VMBO metaal: fijnmechanische techniek Diverse beroepsgroepen

VMBO voertuigentechniek

Monteurs

Chauffeurs

Metaalarbeiders

Andere beroepsgroepen

VMBO elektrotechniek

Elektromonteurs

Monteurs

Chauffeurs

Aannemers en installateurs

Andere beroepsgroepen

VMBO grafische techniek

Diverse beroepsgroepen $\quad 100$

VMBO brood en banket

Diverse beroepsgroepen 100

VMBO transport en logistiek

Chauffeurs

Andere beroepsgroepen

VMBO administratie, handel en mode

Receptionisten en administratieve employés

Verkopers

Boekhouders en secretaresses

Hulpkrachten horeca en verzorging

Interieurverzorgers

Andere beroepsgroepen

stijgend

constant

constant

constant

constant

sterk stijgend

constant

constant

constant

constant

dalend

dalend

VMBO consumptief en levensmiddelentechniek

Hulpkrachten horeca en verzorging

Verkopers

Interieurverzorgers

Bedrijfshoofden horeca

dalend

sterk stijgend

dalend

sterk stijgend 
Tabel 3.1 (vervolg)

Belangrijkste beroepsgroepen per opleidingstype, gemiddelde 2000-2001

VMBO consumptief en levensmiddelentechniek (vervolg) Mechanisch operators

Chauffeurs

Andere beroepsgroepen

VMBO (uiterlijke) verzorging

Hulpkrachten horeca en verzorging

Verkopers

Interieurverzorgers

Receptionisten en administratieve employés

Andere beroepsgroepen

VMBO beveiliging

Aspirant politieagenten, soldaten en

beveiligingshulpkrachte

Chauffeurs

Receptionisten en administratieve employés Andere beroepsgroepen

MBO landbouw en veeteelt

Agrarische bedrijfshoofden

Agrarische arbeiders

Verkopers

Andere beroepsgroepen

MBO milieu en groene ruimte

Agrarische arbeiders

Agrarische bedrijfshoofden

Andere beroepsgroepen

MBO laboratorium

Laboranten

Apothekersassistenten en medisch laboranten

Boekhouders en secretaresses

MBO bouw

Andere beroepsgroepen

sterk dalend

constant

constant

constant

constant

constant

Aannemers en installateurs

Bouwvakkers

Architecten en bouwkundig projectleiders

Andere beroepsgroepen

dalend

sterk stijgend

dalend

constant

sterk stijgend

constant

-

MBO grond-. weg- en waterbouw

Weg- en waterbouwkundige vakkrachten

Aannemers en installateurs

Weg- en waterbouwkundige arbeiders

Weg- en waterbouwkundig ontwerpers en projectleiders

Productiemedewerkers

Andere beroepsgroepen

constant

constant

sterk stijgend

$\mathrm{MBO}$ installatietechniek

Aannemers en installateurs

Monteurs

Bouwvakkers

Andere beroepsgroepen

constant

sterk stijgend

sterk dalend

constant

stijgend

stijgend

$\mathrm{MBO}$ werktuigbouw en mechanische techniek

Monteurs

constant

Bankwerkers en lassers

Metaalarbeiders

Aannemers en installateurs

constant

constant

Andere beroepsgroepen

constant

MBO fijnmechanische techniek

Bankwerkers en lassers

Andere beroepsgroepen

constant 
Tabel 3.1 (vervolg)

Belangrijkste beroepsgroepen per opleidingstype, gemiddelde 2000-2001

MBO motorvoertuigentechniek

Monteurs

Chauffeurs

Assembleurs

Andere beroepsgroepen

constant

constant

constant

MBO vliegtuigtechniek

Diverse beroepsgroepen 100

MBO operationele techniek

Weg- en waterbouwkundige vakkrachten

Andere beroepsgroepen

MBO elektrotechniek

Elektromonteurs

Monteurs

Programmeurs

Andere beroepsgroepen

MBO grafische techniek

Grafische vakkrachten

Grafisch productiepersoneel

Grafisch ontwerpers

Commercieel employés

Andere beroepsgroepen

MBO procestechniek

Procesoperators

Mechanisch operators

Andere beroepsgroepen

MBO brood en banket

Bakkers en slagers

Procesoperators

Andere beroepsgroepen

MBO levensmiddelentechniek/vleesverwerking

Mechanisch operators

Procesoperators

Bakkers en slagers

Andere beroepsgroepen

MBO vervoer en logistiek

Chauffeurs

Productieplanners

Schippers en conducteurs

Administratieve transportemployés

Monteurs

Rij-instructeurs

Boekhouders en secretaresses

Laders en lossers

Andere beroepsgroepen

sterk stijgend

dalend

dalend

sterk stijgend

dalend

sterk stijgend

stijgend

constant

sterk stijgend

constant

sterk dalend

dalend

constant

dalend

constant

sterk stijgend

constant

constant

sterk stijgend

stijgend

MBO dokters-. tandarts- en dierenartsassistent

Verplegenden en doktersassistenten

Boekhouders en secretaresses

Medisch secretaresses

Andere beroepsgroepen

constant

-

dalend

MBO apothekersassistent

Apothekersassistenten en medisch laboranten

Andere beroepsgroepen

constant 
Tabel 3.1 (vervolg)

Belangrijkste beroepsgroepen per opleidingstype, gemiddelde 2000-2001

MBO verpleging

Verplegenden en doktersassistenten

Verzorgend personeel

Therapeuten en verpleegkundigen

Andere beroepsgroepen

MBO gezondheidstechniek

Apothekersassistenten en medisch laboranten

Andere beroepsgroepen

MBO sociaal-cultureel

Verzorgend personeel

Activiteitenbegeleiders en medewerkers arbeidsbemiddeling

Boekhouders en secretaresses

Therapeuten en verpleegkundigen

Andere beroepsgroepen

MBO verzorging

Ziekenverzorgenden

Verzorgend personeel

Boekhouders en secretaresses

Hulpkrachten horeca en verzorging Andere beroepsgroepen

MBO uiterlijke verzorging

Verzorgend personeel

Verkopers

Boekhouders en secretaresses

Andere beroepsgroepen

MBO horeca

Verzorgend personeel

Bedrijfshoofden horeca

Hulpkrachten horeca en verzorging

Boekhouders en secretaresses

Commercieel employés

Andere beroepsgroepen

MBO beweging en therapie

Therapeuten en verpleegkundigen

Activiteitenbegeleiders en medewerkers arbeidsbemiddeling

Sportinstructeurs

Verzorgend personeel

Andere beroepsgroepen

MBO administratie

Boekhouders en secretaresses

Commercieel employés

Receptionisten en administratieve employés

MBO hande

Andere beroepsgroepen

\begin{tabular}{|c|c|}
\hline $\begin{array}{r}51 \\
11 \\
6 \\
31\end{array}$ & $\begin{array}{l}\text { constant } \\
\text { dalend } \\
\text { - }\end{array}$ \\
\hline $\begin{array}{l}74 \\
26\end{array}$ & constant \\
\hline 19 & stijgend \\
\hline $\begin{array}{r}19 \\
9 \\
6 \\
47\end{array}$ & $\begin{array}{l}\text { constant } \\
\text { - } \\
\text { sterk stijgend }\end{array}$ \\
\hline $\begin{array}{r}27 \\
21 \\
6 \\
6 \\
40\end{array}$ & $\begin{array}{l}\text { stijgend } \\
\text { dalend } \\
\text { stijgend } \\
\text { constant }\end{array}$ \\
\hline $\begin{array}{r}47 \\
12 \\
7 \\
34\end{array}$ & $\begin{array}{l}\text { constant } \\
\text { stijgend } \\
\text { - }\end{array}$ \\
\hline $\begin{array}{r}24 \\
14 \\
9 \\
7 \\
6 \\
42\end{array}$ & $\begin{array}{l}\text { dalend } \\
\text { constant } \\
\text { dalend } \\
\text { sterk stijgend } \\
\text { sterk stijgend }\end{array}$ \\
\hline 21 & sterk stijgend \\
\hline $\begin{array}{r}12 \\
11 \\
5 \\
51\end{array}$ & $\begin{array}{l}\text { sterk dalend } \\
\text { - } \\
\text { - }\end{array}$ \\
\hline $\begin{array}{r}36 \\
11 \\
5 \\
47\end{array}$ & $\begin{array}{l}\text { constant } \\
\text { constant } \\
\text { stijgend }\end{array}$ \\
\hline $\begin{array}{r}14 \\
14 \\
9 \\
9 \\
5\end{array}$ & $\begin{array}{l}\text { constant } \\
\text { dalend } \\
\text { stijgend } \\
\text { constant } \\
\text { dalend }\end{array}$ \\
\hline
\end{tabular}

Winkeliers

Verkopers

Boekhouders en secretaresses

Commercieel employés

Commercieel medewerkers

Andere beroepsgroepen 
Tabel 3.1 (vervolg)

Belangrijkste beroepsgroepen per opleidingstype, gemiddelde 2000-2001

MBO secretariaat

Boekhouders en secretaresses

Receptionisten en administratieve employés

Commercieel employés

Medisch secretaresses

Andere beroepsgroepen

MBO toerisme en recreatie

Commercieel employés

Boekhouders en secretaresses

Receptionisten en administratieve employés

Commercieel medewerkers

Andere beroepsgroepen

MBO bedrijfskunde

Boekhouders en secretaresses

Commercieel employés

Winkeliers

Managers

Andere beroepsgroepen

MBO automatisering

Programmeurs

Systeemanalisten

Boekhouders en secretaresses

Andere beroepsgroepen

MBO geld, bank en belastingen

Juridisch en fiscaal medewerkers

Commercieel employés

Commercieel medewerkers

Boekhouders en secretaresses

Andere beroepsgroepen

\begin{tabular}{|c|c|}
\hline 48 & constant \\
\hline 13 & - \\
\hline 7 & constant \\
\hline 7 & constant \\
\hline \multicolumn{2}{|l|}{26} \\
\hline 34 & - \\
\hline 19 & stijgend \\
\hline 13 & - \\
\hline 7 & - \\
\hline \multicolumn{2}{|l|}{27} \\
\hline 14 & stijgend \\
\hline 6 & sterk dalend \\
\hline 5 & - \\
\hline 5 & - \\
\hline \multicolumn{2}{|l|}{70} \\
\hline 38 & stijgend \\
\hline 10 & dalend \\
\hline 8 & constant \\
\hline \multicolumn{2}{|l|}{44} \\
\hline 27 & dalend \\
\hline 17 & constant \\
\hline 16 & constant \\
\hline 13 & - \\
\hline \multicolumn{2}{|l|}{27} \\
\hline 49 & dalend \\
\hline 13 & sterk stijgend \\
\hline 9 & - \\
\hline 7 & - \\
\hline 6 & - \\
\hline \multicolumn{2}{|l|}{16} \\
\hline 35 & dalend \\
\hline 9 & stijgend \\
\hline 57 & \\
\hline
\end{tabular}

MBO verzekeringswezen

Commercieel employés

Commercieel medewerkers

Boekhouders en secretaresses

Receptionisten en administratieve employés

Verzekeringsagenten

Andere beroepsgroepen

MBO openbare orde en veiligheid

Politieagenten, onderofficieren en beveiligings-

employés

Aspirant politieagenten, soldaten en beveiligings-

hulpkrachten

Andere beroepsgroepen

onstant

constant

constant

stijgend

stijgend

dalend

stijgend

dalend

dalend

constant

dalend

sterk stijgend 
Tabel 3.2

Uitwijkmogelijkheden naar verschillende beroepsgroepen per opleidingstype, gemiddelde 2000 2001

Opleidingstype

spreidingsindex

typering

\section{VMBO}

VMBO Landbouw en natuurlijke omgeving VMBO landbouw en natuurlijke omgeving

$8,17 \quad$ gemiddeld

VMBO Techniek

VMBO bouwtechniek

VMBO installatietechniek

VMBO metaal: mechanische techniek

VMBO metaal: fijnmechanische techniek

VMBO voertuigentechniek

VMBO elektrotechniek

VMBO grafische techniek

VMBO brood en banket

VMBO transport en logistiek

$\begin{aligned} 4,65 & \text { laag } \\ 3,36 & \text { laag } \\ 10,27 & \text { gemiddeld } \\ 10,79 & \text { hoog } \\ 7,37 & \text { gemiddeld } \\ 14,83 & \text { hoog } \\ 9,16 & \text { gemiddeld } \\ 16,79 & \text { hoog } \\ 2,33 & \text { erg laag }\end{aligned}$

VMBO Economie

VMBO administratie, handel en mode

15,76

12,58

hoog

VMBO consumptief en levensmiddelentechniek

hoog

VMBO Zorg en welzijn

VMBO (uiterlijke) verzorging

11,48 hoog

VMBO Beveiliging

VMBO beveiliging

4,60

laag

MBO

MBO Landbouw en natuurlijke omgeving

$M B O$ landbouw en veeteelt

MBO milieu en groene ruimte

$5,74 \quad$ gemiddeld

$4,14 \quad$ laag

MBO Techniek

MBO laboratorium

MBO bouw

MBO grond-, weg- en waterbouw

9,10

4,13

gemiddeld

MBO installatietechniek

7,39

3,02

MBO werktuigbouw en mechanische techniek

9,20

MBO fijnmechanische techniek

MBO motorvoertuigentechniek

MBO vliegtuigtechniek

4,11
4,79

MBO operationele techniek

4,69

MBO elektrotechniek

9,02

6,59

MBO grafische techniek

4,34

MBO procestechniek

4,34
7,02

MBO levensmiddelentechniek/vleesverwerking

10,62

MBO vervoer en logistiek

12,45

laag

gemiddeld

laag

gemiddeld

laag

gemiddeld

gemiddeld

gemiddeld

gemiddeld

laag

gemiddeld

gemiddeld

MBO Dienstverlening en gezondheidszorg

MBO dokters-, tandarts- en dierenartsassistent

hoog

MBO apothekersassistent

erg laag

$M B O$ verpleging

erg laag

MBO gezondheidstechniek

laag

MBO sociaal-cultureel

10,20

erg laag

gemiddeld 
Tabel 3.2 (vervolg)

Uitwijkmogelijkheden naar verschillende beroepsgroepen per opleidingstype, gemiddelde 20002001

Opleidingstype

spreidingsindex

typering

MBO Dienstverlening en gezondheidszorg (vervolg)

$M B O$ verzorging

7,53 gemiddeld

MBO uiterlijke verzorging

MBO horeca

3,92

laag

MBO beweging en therapie

gemiddeld

MBO Economie

MBO administratie

MBO handel

10,77

gemiddeld

MBO secretariaat

MBO toerisme en recreatie

MBO bedrijfskunde

MBO automatisering

MBO geld, bank en belastingen

$M B O$ verzekeringswezen

6,16 gemiddeld

14,92 hoog

$3,81 \quad$ laag

5,30 gemiddeld

21,01 erg hoog

5,51 gemiddeld

6,40 gemiddeld

MBO Openbare orde en veiligheid

$\mathrm{MBO}$ openbare orde en veiligheid

3,56 laag

7,08 gemiddeld 



\section{$4 \quad$ Belangrijkste bedrijfssectoren}

Tabel 4.1

Belangrijkste bedrijfssectoren per opleidingstype, gemiddelde 2000-2001

VMBO landbouw en natuurlijke omgeving

Veehouderij

Handel en reparatie

Tuinbouw

Bouw

Hout- en bouwmaterialen

Akkerbouw, bosbouw en visserij

Andere bedrijfssectoren

VMBO bouwtechniek

Bouw

Hout- en bouwmaterialen

Handel en reparatie

Weg-en railvervoer

Andere bedrijfssectoren

$-2001$

MBO installatietechniek

Bouw

Andere bedrijfssectoren

dalend

constant

sterk stijgend

sterk dalend

sterk stijgend

sterk dalend

33

constant

constant

sterk dalend

sterk stijgend

sterk dalend

VMBO metaal: mechanische techniek Bouw

Metaalproducten

Handel en reparatie

Machine-industrie

Weg- en railvervoer

Hout- en bouwmaterialen

Transportmiddelen

Andere bedrijfssectoren

sterk stijgend

dalend

dalend

constant

sterk dalend

constant

sterk dalend

VMBO metaal: fijnmechanische techniek

Diverse bedrijfssectoren

VMBO voertuigentechniek

Handel en reparatie

Weg- en railvervoer

Bouw

Andere bedrijfssectoren

constant

dalend

sterk stijgend

VMBO elektrotechniek

Bouw

Handel en reparatie

Zakelijke dienstverlening

Andere bedrijfssectoren

stijgend

sterk stijgend

sterk dalend

VMBO grafische techniek

Grafische industrie

Andere bedrijfssectoren

stijgend

VMBO brood en banket

Overige voedingsproducten

Andere bedrijfssectoren

VMBO transport en logistiek

Weg- en railvervoer

Handel en reparatie

Bouw

Andere bedrijfssectoren

dalend

constant

sterk dalend

sterk stijgend 
Tabel 4.1 (vervolg)

Belangrijkste bedrijfssectoren per opleidingstype, gemiddelde 2000-2001

VMBO administratie.handel en mode

Handel en reparatie

Gezondheidszorg

Zakelijke dienstverlening

Overheid

Andere bedrijfssectoren

VMBO consumptief en levensmiddelentechniek

Horeca

Handel en reparatie

Gezondheidszorg

Zakelijke dienstverlening

Overheid

Andere bedrijfssectoren

iterlijke) verzorging

Gezondheidszorg

Handel en reparatie

Zakelijke dienstverlening

Horeca

Overige commerciële dienstverlening

Andere bedrijfssectoren

VMBO beveiliging

Zakelijke dienstverlening

Overheid

Handel en reparatie

Bouw

Gezondheidszorg

Andere bedrijfssectoren

$\mathrm{MBO}$ landbouw en veeteelt

Veehouderij

Handel en reparatie

Tuinbouw

Akkerbouw, bosbouw en visserij

Andere bedrijfssectoren

MBO milieu en groene ruimte

Overheid

Veehouderij

Handel en reparatie

Hout- en bouwmaterialen

Tuinbouw

Zakelijke dienstverlening

Andere bedrijfssectoren

MBO laboratorium

Gezondheidszorg

Eindproducten chemie

Handel en reparatie

Overheid

Overige kwartaire diensten

Andere bedrijfssectoren

MBO bouw

$$
\text { Bouw }
$$

Hout- en bouwmaterialen

Zakelijke dienstverlening

Handel en reparatie

Andere bedrijfssectoren

dalend

sterk stijgend

constant

constant

45

27

dalend

stijgend

sterk stijgend

constant

sterk stijgend

sterk stijgend

dalend

dalend

constant

sterk stijgend

constant

stijgend

constant

sterk stijgend

sterk stijgend

dalend

sterk stijgend

stijgend

sterk dalend

stijgend

dalend

dalend

sterk stijgend

sterk stijgend

dalend

sterk dalend

sterk stijgend

constant

constant

dalend

constant

dalend

stijgend

stijgend 
Tabel 4.1 (vervolg)

Belangrijkste bedrijfssectoren per opleidingstype, gemiddelde 2000-2001

MBO grond-, weg- en waterbouw Bouw

Overheid

Zakelijke dienstverlening

Andere bedrijfssectoren

MBO installatietechniek

Bouw

Handel en reparatie

Andere bedrijfssectoren

rktuigbouw en mechanische techniek

Machine-industrie

Metaalproducten

Handel en reparatie

Bouw

Zakelijke dienstverlening

Transportmiddelen

Andere bedrijfssectoren

MBO fijnmechanische techniek

Handel en reparatie

Andere bedrijfssectoren

MBO motorvoertuigentechniek

Handel en reparatie

Weg- en railvervoer

Andere bedrijfssectoren

\section{0}

25

12

24

63

7

30

15

14

13

9

6

6

6
36

31

69

58

9

33

MBO vliegtuigtechniek

Diverse bedrijfssectoren

MBO operationele techniek

Bouw

Andere bedrijfssectoren

100

43

57

MBO elektrotechniek

Bouw

Handel en reparatie

Zakelijke dienstverlening

Elektrotechniek

Communicatie

Andere bedrijfssectoren

MBO grafische techniek

Grafische industrie

Zakelijke dienstverlening

Handel en reparatie

Andere bedrijfssectoren

MBO procestechniek

Basischemie

Basismetaal

Eindproducten chemie

Overige voedingsproducten

Energie

Handel en reparatie

Elektrotechniek

Andere bedrijfssectoren

MBO brood en banket

Overige voedingsproducten

Handel en reparatie

Zakelijke dienstverlening

Andere bedrijfssectoren stijgend

stijgend

sterk dalend

constant

sterk stijgend

dalend

constant

sterk stijgend

constant

stijgend

dalend

dalend

stijgend

dalend

stijgend

constant

constant

sterk stijgend

constant

stijgend

dalend

dalend

constant

constant

stijgend

dalend

stijgend

sterk stijgend

stijgend

sterk stijgend

dalend

sterk stijgend

sterk stijgend 
Tabel 4.1 (vervolg)

Belangrijkste bedrijfssectoren per opleidingstype, gemiddelde 2000-2001

MBO levensmiddelentechniek/vleesverwerking

Handel en reparatie

Overige voedingsproducten

Vlees- en visverwerking

Zakelijke dienstverlening

Andere bedrijfssectoren

$\mathrm{MBO}$ vervoer en logistiek

Weg- en railvervoer

Handel en reparatie

Onderwijs

Scheep- en luchtvaart

Andere bedrijfssectoren

MBO dokters-, tandarts- en dierenartsassistent

Gezondheidszorg

Handel en reparatie

Andere bedrijfssectoren

MBO apothekersassistent

Handel en reparatie

Gezondheidszorg

Andere bedrijfssectoren

$M B O$ verpleging

Gezondheidszorg

Andere bedrijfssectoren

MBO gezondheidstechniek

Handel en reparatie

Andere bedrijfssectoren

MBO sociaal-cultureel

Gezondheidszorg

Overheid

Handel en reparatie

Zakelijke dienstverlening

Andere bedrijfssectoren

$\mathrm{MBO}$ verzorging

Gezondheidszorg

Handel en reparatie

Andere bedrijfssectoren

MBO uiterlijke verzorging

Overige commerciële dienstverlening

Handel en reparatie

Gezondheidszorg

Andere bedrijfssectoren

$\mathrm{MBO}$ horeca

Horeca

Handel en reparatie

Gezondheidszorg

Zakelijke dienstverlening

Andere bedrijfssectoren

MBO beweging en therapie

Gezondheidszorg

Overige commerciële dienstverlening

Overheid

Handel en reparatie

Andere bedrijfssectoren dalend

sterk stijgend

sterk dalend

sterk stijgend

29

38

12

stijgend

sterk stijgend

sterk stijgend

sterk dalend

37

74

constant

dalend

20

63

20

17

86

14

64

36

51

13

6

22

constant

sterk dalend

constant

sterk stijgend

stijgend

sterk stijgend

dalend

dalend

constant

dalend

24

47

21

constant

stijgend

sterk dalend

sterk stijgend

constant

sterk dalend

dalend

dalend

sterk stijgend

sterk stijgend

sterk stijgend 
Tabel 4.1 (vervolg)

Belangrijkste bedrijfssectoren per opleidingstype, gemiddelde 2000-2001

MBO administratie

Handel en reparatie

Zakelijke dienstverlening

Overheid

Bankwezen

Gezondheidszorg

Andere bedrijfssectoren

MBO handel

Handel en reparatie

Zakelijke dienstverlening

Andere bedrijfssectoren

MBO secretariaat

Gezondheidszorg

Zakelijke dienstverlening

Handel en reparatie

Overheid

Andere bedrijfssectoren

MBO toerisme en recreatie

Weg- en railvervoer

Handel en reparatie

Zakelijke dienstverlening

Bankwezen

Overheid

Horeca

Andere bedrijfssectoren

MBO bedrijfskunde

Handel en reparatie

Zakelijke dienstverlening

Gezondheidszorg

Overheid

Andere bedrijfssectoren

$\mathrm{MBO}$ automatisering

Zakelijke dienstverlening

Handel en reparatie

Overheid

Andere bedrijfssectoren

MBO geld, bank en belastingen

Overheid

Bankwezen

Zakelijke dienstverlening

Verzekeringswezen

Andere bedrijfssectoren

MBO verzekeringswezen

Verzekeringswezen

Bankwezen

Zakelijke dienstverlening

Overheid

Andere bedrijfssectoren

MBO openbare orde en veiligheid

Overheid

Handel en reparatie

Zakelijke dienstverlening

Andere bedrijfssectoren

\begin{tabular}{|c|c|}
\hline 18 & \\
\hline 15 & constant \\
\hline 14 & constant \\
\hline 7 & stijgend \\
\hline 6 & sterk stijgend \\
\hline 40 & \\
\hline 45 & constant \\
\hline 8 & sterk stijgend \\
\hline 46 & \\
\hline 20 & constant \\
\hline 14 & constant \\
\hline 12 & dalend \\
\hline 9 & stijgend \\
\hline 45 & \\
\hline 33 & dalend \\
\hline 10 & sterk stijgend \\
\hline 9 & sterk dalend \\
\hline 7 & sterk dalend \\
\hline 7 & sterk stijgend \\
\hline 7 & sterk stijgend \\
\hline 26 & \\
\hline 21 & sterk stijgend \\
\hline 11 & sterk stijgend \\
\hline 9 & dalend \\
\hline 8 & stijgend \\
\hline 51 & \\
\hline 26 & constant \\
\hline 16 & sterk stijgend \\
\hline 11 & constant \\
\hline 46 & \\
\hline 39 & dalend \\
\hline 29 & dalend \\
\hline 8 & sterk stijgend \\
\hline 6 & sterk dalend \\
\hline 18 & \\
\hline 58 & constant \\
\hline 17 & constant \\
\hline 8 & stijgend \\
\hline 5 & sterk stijgend \\
\hline 12 & \\
\hline 59 & dalend \\
\hline 7 & constant \\
\hline 5 & stijgend \\
\hline
\end{tabular}


Tabel 4.2

Uitwijkmogelijkheden naar verschillende bedrijfssectoren per opleidingstype, gemiddelde 2000 2001

Opleidingstype

spreidingsindex

typering

\section{VMBO}

VMBO Landbouw en natuurlijke omgeving VMBO landbouw en natuurlijke omgeving

$5,43 \quad$ gemiddeld

VMBO Techniek

VMBO bouwtechniek

VMBO installatietechniek

VMBO metaal: mechanische techniek

VMBO metaal: fijnmechanische techniek

VMBO voertuigentechniek

4,73

3,00

13,77

12,65

9,10

VMBO elektrotechniek

10,69
5,38

VMBO grafische techniek

VMBO brood en banket

9,39

VMBO transport en logistiek

4,44

VMBO Economie

VMBO administratie, handel en mode

13,09 hoog

VMBO consumptief en levensmiddelentechniek

gemiddeld

VMBO Zorg en welzijn

VMBO (uiterlijke) verzorging

8,76 gemiddeld

VMBO Beveiliging

VMBO beveiliging

5,87

gemiddeld

MBO

MBO Landbouw en natuurlijke omgeving

$\mathrm{MBO}$ landbouw en veeteelt

MBO milieu en groene ruimte

$3,43 \quad$ laag

6,08 gemiddeld

MBO Techniek

$\mathrm{MBO}$ laboratorium

MBO bouw

MBO grond-, weg- en waterbouw

9,21

3,05

4,19

gemiddeld

hoog

hoog

gemiddeld

hoog

gemiddeld

gemiddeld

MBO installatietechniek

2,43

13,79

10,76

MBO fijnmechanische techniek

4,39

5,84

4,51

MBO vliegtuigtechniek

10,96

3,99

MBO elektrotechniek

6,82

grafische technie

6,82
4,17

MBO brood en banket

MBO levensmiddelentechniek/vleesverwerking

5,54

MBO vervoer en logistiek

8,67

gemiddeld

laag

gemiddeld

laag

hoog

hoog

gemiddeld

gemiddeld

gemiddeld

hoog

gemiddeld

gemiddeld

gemiddeld

gemiddeld

MBO Dienstverlening en gezondheidszorg

MBO dokters-, tandarts- en dierenartsassistent

1,78 gemiddeld

MBO apothekersassistent

2,44

erg laag

$M B O$ verpleging

laag

MBO gezondheidstechniek

1,34

2,29

MBO sociaal-cultureel

3,47

erg laag

laag

laag

64 
Tabel 4.2 (vervolg)

Uitwijkmogelijkheden naar verschillende bedrijfssectoren per opleidingstype, gemiddelde 20002001

Opleidingstype

spreidingsindex

typering

MBO Dienstverlening en gezondheidszorg (vervolg)

$\mathrm{MBO}$ verzorging

MBO uiterlijke verzorging

MBO horeca

MBO beweging en therapie

$2,10 \quad$ erg laag

3,88 gemiddeld

4,96 gemiddeld

MBO Economie

MBO administratie

3,36

laag

MBO handel

MBO secretariaat

$\mathrm{MBO}$ toerisme en recreatie

MBO bedrijfskunde

MBO automatisering

MBO geld, bank en belastingen

$M B O$ verzekeringswezen

14,65 erg hoog

8,02 gemiddeld

12,11 hoog

8,02 gemiddeld

19,62 erg hoog

12,78 hoog

$4,09 \quad$ gemiddeld

MBO Openbare orde en veiligheid

$\mathrm{MBO}$ openbare orde en veiligheid

4,59 gemiddeld

$2,78 \quad$ laag 